NBER WORKING PAPER SERIES

\title{
MONETARY-FISCAL POLICY INTERACTIONS AND THE PRICE LEVEL: BACKGROUND AND BEYOND
}

\author{
Eric M. Leeper \\ Tack Yun \\ Working Paper 11646 \\ http://www.nber.org/papers/w11646
NATIONAL BUREAU OF ECONOMIC RESEARCH
1050 Massachusetts Avenue
Cambridge, MA 02138
September 2005

Date: September 16, 2005. Department of Economics, Indiana University and NBER, eleeper@indiana.edu; Monetary Affairs Division, Federal Reserve Board, Tack.Yun@frb.gov. Prepared for the 61st Congress of the International Institute of Public Finance conference "Macro-Fiscal Policies: New Perspectives and Challenges," Jeju Island, South Korea, August 22-25, 2005. Leeper acknowledges support of NSF Grant SES-0452599. The views expressed here are those of the authors and do not necessarily reflect the views of the Board of Governors of the Federal Reserve System. The views expressed herein are those of the author(s) and do not necessarily reflect the views of the National Bureau of Economic Research.

(O)2005 by Eric M. Leeper and Tack Yun. All rights reserved. Short sections of text, not to exceed two paragraphs, may be quoted without explicit permission provided that full credit, including $\odot$ notice, is given to the source. 
Monetary-Fiscal Policy Interactions and the Price Level: Background and Beyond Eric M. Leeper and Tack Yun

NBER Working Paper No. 11646

September 2005

JEL No. E31, E52, E62

\title{
ABSTRACT
}

The paper presents the fiscal theory of the price level in a variety of models, including endowment economies with lump-sum taxes and production economies with proportional income taxes. We offer a microeconomic perspective on the fiscal theory by computing a Slutsky-Hicks decomposition of the effects of tax changes into substitution, wealth, and revaluation effects. Revaluation effects arise whenever tax changes alter the value of outstanding nominal government liabilities by changing the price level. Under certain assumptions on monetary and fiscal behavior, the revaluation effect reflects the fiscal theory mechanism. When taxes distort, two Laffer curves arise, implying that a tax increase can lower or raise the price level and the revaluation effect can be positive or negative, depending on which side of a particular Laffer curve the economy resides.

\author{
Eric M. Leeper \\ Department of Economics \\ 304 Wylie Hall \\ Indiana University \\ Bloomington, IN 47405 \\ and NBER \\ eleeper@indiana.edu \\ Tack Yun \\ Federal Reserve Board \\ Monetary Studies Section \\ Division of Monetary Affairs \\ $20^{\text {th }}$ Street and Constitution Avenue NW \\ Washington, DC 20551 \\ tack.yun@frb.gov
}




\title{
MONETARY-FISCAL POLICY INTERACTIONS AND THE PRICE LEVEL: BACKGROUND AND BEYOND
}

\author{
ERIC M. LEEPER AND TACK YUN
}

\section{InTRODUCTION}

Occasionally a new idea in macroeconomics generates professional reactions that are, in equal parts, excitement and vitriol. The fiscal theory of the price level is such an idea. It is provocative because it attributes to fiscal policy a potentially important role in determining the general level of prices in the economy, placing it in direct competition with the venerable quantity theory of money. At the same time, the fiscal theory constitutes a new channel for breaking Ricardian equivalence one that comes from the valuation of nominal government liabilities. Unlike existing methods for deviating from Ricardian equivalence, which rely on market imperfections, myopic consumers, or tax distortions, the fiscal theory arises from particular combinations of monetary and fiscal policies.

The label "the fiscal theory of the price level" would seem to imply that fiscal policy alone determines the price level, and this is certainly the tone of several papers on the topic. We regard the label to be a misnomer. In all theories of price level determination - whether the fiscal theory or the quantity theory - the equilibrium price level emerges from particular combinations of monetary and fiscal policy behavior. In both theories it is impossible to even derive an equilibrium without completely specifying both monetary and fiscal behavior. Where the theories part company is in their predictions of how monetary or fiscal changes affect the price level.

The fiscal theory lurks in any dynamic model with monetary and fiscal policies. The theory's linchpin is a ubiquitous dynamic equilibrium condition that equates the real value of total nominal government liabilities - typically high-powered money plus unindexed debt - to the expected discounted present value of net-of-interest surpluses

Date: September 16, 2005. Department of Economics, Indiana University and NBER, eleeper@indiana.edu; Monetary Affairs Division, Federal Reserve Board, Tack.Yun@frb.gov. Prepared for the 61st Congress of the International Institute of Public Finance conference "Macro-Fiscal Policies: New Perspectives and Challenges," Jeju Island, South Korea, August 22-25, 2005. Leeper acknowledges support of NSF Grant SES-0452599. The views expressed here are those of the authors and do not necessarily reflect the views of the Board of Governors of the Federal Reserve System. 
plus seigniorage. ${ }^{1}$ This condition stems from combining the government's intertemporal budget constraint with some private-sector optimality conditions. Critiques of the fiscal theory spring, in large part, from interpretations of the role this condition plays in determining equilibrium.

This paper tries to avoid the controversy surrounding the fiscal theory by describing it in ways that do not get mired in interpretation of the contentious equilibrium condition. Instead, the paper takes a more microeconomic approach to show how the fiscal theory works in several conventional models. First, section 2 uses a permanent income model to describe the fiscal theory mechanism in partial equilibrium terms. In section 3 we present a textbook exposition of the theory using a simple general equilibrium model with lump-sum taxes. Although patently unrealistic, lump-sum taxes serve the useful purpose of isolating demand-side impacts of taxes. In this environment, higher taxes unambiguously lower the price level by raising the expected present value of surpluses. Section 4 presents some results from recent work on simple monetary and tax policy rules, framing the backdrop for the fiscal theory.

Although instructive for some purposes, the assumption that all taxes are lump sum prevents the fiscal theory from being understood in the context of the broader public finance literature. Section 5 addresses this, first by introducing income taxes and elastic labor supply, and second by decomposing the total effect of a tax change into conventional substitution and wealth effects plus an asset revaluation effect. The revaluation effect arises when tax changes alter the equilibrium price level and, therefore, the real value of outstanding nominal government liabilities. This revaluation effect is always present in economies with nominal government liabilities. Under the fiscal theory, where fiscal policy affects the price level through the ubiquitous dynamic equilibrium condition, the revaluation effect is the first step in the transmission of fiscal disturbances. This leads to viewing the fiscal theory as operative whenever certain monetary-fiscal policy combinations imply that the dynamic equilibrium condition imposes restrictions on the equilibrium price-level process.

The paper extends examination of the fiscal theory of the price level to a model with the simplest kind of tax distortion - a proportional labor income tax. Introducing supply-side effects of taxes produces a richer set of possible implications from the fiscal theory. Tax hikes can lower or raise the price level, depending on whether they raise

\footnotetext{
${ }^{1}$ The notion that the fiscal theory of the price level can be the mechanism that determines the general level of prices and inflation potentially applies to any economy where the government sells debt denominated in its home currency. This encompasses a great many countries, including, for example, most OECD countries. Countries that issue "real debt" (indexed to inflation or denominated in foreign currency) are still susceptible to the mechanism that the fiscal theory highlights, but their only recourse is outright debt default.
} 
or lower the expected present value of surpluses plus seigniorage. This intertemporal link between tax rates and the government's budget represents a new type of Laffer curve that, under the fiscal theory, is central to determining the impacts of fiscal changes on the economy.

Microeconomic public finance economists should care about the fiscal theory because it identifies a new channel by which fiscal policies can affect economic activity. This channel is typically absent from both micro and macro models of taxation. Whether the channel shows up entirely in inflation or in some split among inflation, real interest rates, and output depends on details about how the economy works and the nature of the tax code. But even if the fiscal theory mechanism only generates inflation, it can have important distributional impacts that affect the incidence of taxation. Accounting for these effects may be important for designing tax systems.

Because the fiscal theory is an intrinsically general equilibrium phenomenon, any discussion of the theory must explicitly account for monetary policy behavior. The theory underscores that monetary and fiscal policies cannot coherently be understood in isolation from each other. It also implies that the design of tax and monetary systems should be a joint endeavor. Although in practice monetary and fiscal systems tend to be disjoint - witness the European Monetary System and the development of monetary union - recent research on optimal policy recognizes the importance of considering monetary and fiscal policies jointly [Benigno and Woodford (2003), Eggertsson and Woodford (2004), and Schmitt-Grohe and Uribe (2004a,b)].

There is plenty of precedent for this topic that predates more recent, formal discussion. Important work includes Friedman (1948, 1960), Brunner and Meltzer (1972, 1993), and Tobin (1961, 1969, 1980). Sargent and Wallace (1981) lay the foundation for understanding monetary and fiscal policy interactions in dynamic economies. Aiyagari and Gertler (1985) is a relatively recent important contribution. What is referred to as "the fiscal theory of the price level," developed in Leeper (1991, 1993), Sims (1994), and Woodford (1994, 1995), is now part of standard graduate macro curricula [Elmendorf and Mankiw (1999), Ljungqvist and Sargent (2004), Walsh (2003), and Woodford (2003)].

\section{A Permanent Income Exposition of the Fiscal Theory}

The permanent income hypothesis of consumption, as Hall (1978) framed it, can clearly explain the mechanism underlying the fiscal theory of the price level. The household makes a consumption-saving decision. It receives a sequence of labor incomes, $\left\{y_{t}\right\}$, pays taxes, $\left\{\tau_{t}\right\}$, and saves in the form of nominal assets, $\left\{A_{t+1}\right\}$, which consist of government debt and money, $A_{t}=M_{t-1}+B_{t-1}$. To simplify the exposition, we assume that assets that pay one unit of consumption goods at $t+1$ sell for $1 / R$ 
at $t$, where $1 / R=\beta$, the household's discount factor. The household chooses the sequences $\left\{c_{t}, M_{t}, A_{t+1}\right\}$ to maximize

$$
E_{0} \sum_{t=0}^{\infty} \beta^{t}\left[u\left(c_{t}\right)+v\left(M_{t} / P_{t}\right)\right], \quad 0<\beta<1,
$$

where $u$ and $v$ are strictly increasing, strictly concave, and differentiable functions, $M_{t} / P_{t}$ is real money balances, and $E_{0}$ is the expectations operator conditional on information available at date 0 , subject to

$$
c_{t}+\frac{i_{t}}{1+i_{t}} \frac{M_{t}}{P_{t}}+\frac{1}{R} \frac{A_{t+1}}{P_{t}}=y_{t}-\tau_{t}+\frac{A_{t}}{P_{t}},
$$

where $i$ is the (net) nominal interest rate, so $i_{t} /\left(1+i_{t}\right)$ is the opportunity cost of holding money.

The present-value form of the household's budget constraint is

$$
\frac{A_{t}}{P_{t}}=E_{t} \sum_{j=0}^{\infty} \frac{1}{R^{j}}\left[c_{t+j}+\frac{i_{t+j}}{1+i_{t+j}} m_{t+j}-y_{t+j}+\tau_{t+j}\right],
$$

where $m_{t}=M_{t} / P_{t}$ is real money balances. ${ }^{2}$ Quadratic preferences make the optimal choice of consumption follow a martingale

$$
c_{t}=E_{t} c_{t+1} .
$$

Imposing (4) on (3) yields the consumption function

$$
c_{t}=(1-\beta)\left\{\frac{M_{t-1}+B_{t-1}}{P_{t}}+E_{t} \sum_{j=0}^{\infty} \frac{1}{R^{j}}\left[y_{t+j}-\tau_{t+j}-\frac{i_{t+j}}{1+i_{t+j}} m_{t+j}\right]\right\},
$$

which makes consumption a constant share of wealth. The first part of wealth is the real value at date $t$ of nominal assets carried over from the previous period and the second part is the expected discounted present value of income after expenditures on taxes and money holdings.

Expression (5) is suggestive as a partial equilibrium description of consumption behavior. It is not general equilibrium because we have not imposed the optimal choice of money, market clearing, or the government's budget constraint. Nonetheless, the consumption function makes clear that ceteris paribus a surprise transitory cut in taxes at time $t$ (lower $\tau_{t}$ ) or an anticipated cut in future taxes (lower $\tau_{t+j}$ ), increase the demand for current consumption goods by raising wealth.

\footnotetext{
${ }^{2}$ Expression (3) has imposed that $\lim _{T \rightarrow \infty} E_{t}\left[R^{-T}\left(A_{T+1} / P_{T}\right)\right]=0$.
} 
The general equilibrium impacts of such a tax reduction depend on details about the model as well as assumptions about how current and expected monetary and fiscal policies respond to the tax cut. To preview the simplest form of the fiscal theory with lump-sum taxes, imagine an environment in which the central bank pegs the nominal interest rate, the fiscal authority refuses to pay for tax reductions with future tax hikes, and prices are flexible. Under these assumptions, lower $\tau_{t}$ raises the expected sum in (5), causing the demand for consumption goods at $t$ to rise. If supply of goods is perfectly inelastic, higher demand drives the aggregate price level up to the point at which households are happy to consume their pre-tax level of goods. Equilibrium is restored when the price level rises sufficiently to reduce the real value of nominal assets enough to exactly offset the increase in after-tax labor income, leaving no change in wealth. This simple analysis embodies the textbook description of the fiscal theory: current or prospective changes in taxes are "financed" through jumps in the price level that revalue outstanding nominal government liabilities [see, for example, Walsh (2003)]. But we cannot formally derive these results without a complete general equilibrium model of the economy.

\section{A Simple General Equilibrium Model}

The simplest general equilibrium model for describing the relationship between monetary and fiscal policies and inflation assumes an endowment economy with lumpsum taxes. This simplification occurs with important loss of generality, as section 5 shows. ${ }^{3}$

3.1. Setup. An infinitely lived representative household is endowed with a constant quantity $y$ of goods each period and chooses $\left\{c_{t}, M_{t}, B_{t}\right\}$ to solve

$$
E_{0} \sum_{t=0}^{\infty} \beta^{t}\left[u\left(c_{t}+g_{t}\right)+v\left(M_{t} / P_{t}\right)\right], \quad 0<\beta<1,
$$

subject to

$$
c_{t}+\frac{M_{t}}{P_{t}}+\frac{B_{t}}{P_{t}}+\tau_{t} \leq y+\frac{M_{t-1}}{P_{t}}+\frac{\left(1+i_{t-1}\right) B_{t-1}}{P_{t}},
$$

where $M_{t}$ is nominal money balances, $B_{t}$ is a nominal bond that costs $\$ 1$ at $t$ and pays $1+i_{t}$ dollars at $t+1$, and $\tau_{t}$ is lump-sum taxes (if positive) and transfers (if negative). ${ }^{4}$ Initial assets $M_{-1}+B_{-1}>0$ are given. We consider perfect foresight

\footnotetext{
${ }^{3}$ See also Leeper (2003) and Gordon and Leeper (forthcoming).

${ }^{4}$ The assumption in the preference specification, (6), that private and government consumption are perfect substitutes, is not essential. It allows us to couch the discussion in terms of the net-ofinterest fiscal surplus, $\tau_{t}-g_{t}$, instead of tax revenues. In this case, government purchases have the
} 
equilibria, so the $E_{t}$ operator denotes equilibrium expectations of private agents over future policy; it distinguishes between current and past policies (dated $t$ and earlier) and future policies (dates $s>t$ ).

The government chooses $\left\{M_{t}, B_{t}, \tau_{t}\right\}$ to finance a constant level of purchases of goods, $g$, to satisfy the government budget constraint

$$
g=\frac{M_{t}-M_{t-1}}{P_{t}}+\frac{B_{t}-\left(1+i_{t-1}\right) B_{t-1}}{P_{t}}+\tau_{t} .
$$

3.2. Equilibrium. Arbitrage between the two nominal assets - money and bondsequates the marginal rate of substitution between consumption and real money balances to the opportunity cost of holding money:

$$
\frac{v^{\prime}\left(M_{t} / P_{t}\right)}{u^{\prime}\left(c_{t}+g_{t}\right)}=\frac{i_{t}}{1+i_{t}}
$$

Market clearing implies that $c_{t}+g_{t}=y$, for all $t$, and money and bond markets clear by equating the private sector's demand for the assets to the policy authority's supply. Imposing equilibrium yields a simple Fisher relation

$$
\frac{1}{1+i_{t}}=\beta E_{t}\left[\frac{1}{\pi_{t+1}}\right],
$$

where $1 / \beta$ is the constant real interest rate and $\pi_{t+1}=P_{t+1} / P_{t}$ is the gross inflation rate.

We focus on circumstances in which the economy is in a stationary equilibrium at dates $s>t$, but starts from a different equilibrium at $t$. This breaks time into two periods: now and the future. Assume policies are fixed in the future stationary equilibrium:

$$
\tau_{s}=\tau, \quad \mu_{s}=\mu, \quad s>t,
$$

where $\mu_{t}=M_{t} / M_{t-1}$ is the growth rate of the money supply. At $t$, however, policies may be different:

$$
\tau_{t} \neq \tau, \quad \mu_{t} \neq \mu .
$$

In the stationary equilibrium with constant real money balances, inflation depends only on money growth:

$$
\pi=\mu \text {. }
$$

same effect on the economy as transfer payments; because in this section taxes are lump sum, $\tau$ and $g$ have identical effects. 
Combining this with the Fisher relation implies that in the stationary equilibrium the nominal rate depends on money growth,

$$
1+i_{s}=\mu / \beta, \quad s \geq t
$$

so from (9) stationary real balances is

$$
\frac{M_{s}}{P_{s}}=f(\mu), \quad s \geq t
$$

3.3. Equilibrium Expectations. We now derive two versions of the government budget constraint that describe the trade-offs among current and future monetary and fiscal policies that can arise in equilibrium. Imposing equilibrium prices on (8) at $t$,

$$
f(\mu)\left[1+B_{t} / M_{t}-\frac{1}{\mu_{t}}\left(1+\left(1+i_{t-1}\right) B_{t-1} / M_{t-1}\right)\right]=g-\tau_{t} .
$$

For given policies in the (future) stationary equilibrium, (16) reports the feasible trade-offs among current (date $t$ ) policies, when initial government liabilities are $\left(M_{t-1},\left(1+i_{t-1}\right) B_{t-1}\right)$. Imposing equilibrium on the government budget constraint for dates $s>t$, and assuming future policy is anticipated (so $1+i=\mu / \beta)$,

$$
f(\mu)\left[1-1 / \mu+\left(1-\frac{1}{\beta}\right) B / M\right]=g-\tau,
$$

where we assume that $B_{t} / M_{t}=B / M$, so the bond-money ratio is constant in the stationary equilibrium at $B / M$. For a given state of government indebtedness, $B / M$, (17) describes the trade-offs among future policies that are consistent with equilibrium. The bond-money ratio, which links current policies to future policies, can equivalently be thought of in terms of the real value of government debt outstanding or the debt-output ratio.

3.4. Bond-Financed Tax Cut. In the policy experiments we consider, the level of government spending is held fixed at $g$. The experiments take the form of an initial cut in taxes at $t, d \tau_{t}<0$, which is financed by new sales of nominal bonds, and then they consider alternative responses of current and future policies that satisfy (16) and (17). The analysis traces the impacts of each complete specification of policy behavior on the price level and inflation. 
3.4.1. Ricardian equivalence. Hold current and future money growth, $\left(\mu_{t}, \mu\right)$, fixed. By (14) and (15), this policy pegs the nominal interest rate at $1+i=\mu / \beta$ and fixes equilibrium real balances at $f(\mu)$. Neither the initial price level, $P_{t}$, nor the stationary inflation rate, $\pi$, change. A reduction in real taxes today is consistent with equilibrium today if nominal debt expands to satisfy (16) with fixed money growth. This raises $B_{t} / M_{t}$, which by (17) requires that future taxes rise sufficiently to service the new, higher level of government indebtedness. This mix of policies implies Ricardian equivalence: the timing of taxes and debt is irrelevant for equilibrium allocations and prices. The policies also imply monetary policy is independent of fiscal considerations, as the quantity theory of money maintains. Of course, as this exercise illustrates, the quantity theory requires a particular kind of fiscal behavior.

3.4.2. Unpleasant monetarist arithmetic. The central bank holds current money growth, $\mu_{t}$, fixed, while the fiscal authority continues to hold future taxes constant. Because some future policy is free to adjust, it is feasible for current policy to imply more debt in the future. To service that higher debt, future money growth and inflation must rise, increasing the nominal interest rate and reducing real money balances at $t$. Since $M_{t}$ is fixed, $P_{t}$ must rise to clear the money market. It is higher inflation and seigniorage revenues - revenues derived from the "inflation tax" on nominal assetsthat service future debt. Again, with future net-of-interest fiscal deficits held fixed at $g-\tau$, monetary policy is constrained by fiscal needs and, in this case, the central bank loses control of future inflation. ${ }^{5}$

3.4.3. The fiscal theory. The central bank credibly pegs the nominal interest rate by fixing future money growth, $\mu$, and the fiscal authority credibly fixes future taxes, $\tau$. Can this be an equilibrium? With future policies fixed, (17) implies current policies cannot alter government indebtedness in the future, summarized by $B / M$, so the expansion in nominal debt cannot be transformed into higher real debt. $P_{t}$ must rise in proportion to $B_{t}$. But a pegged nominal interest rate fixes real money balances, according to (14) and (15), so the current money stock must expand in proportion to the increase in prices, ensuring no change in $B_{t} / M_{t}$ in (16). The central bank loses control of the current money stock and the price level, as adjustments in these variables are governed by fiscal needs that are beyond the bank's direct control. A pegged nominal rate subordinates current monetary policy to fiscal needs, but this is not "monetization of deficits" in the usual sense of printing money to purchase newly issued government debt. Instead, the expansion in money is a passive adjustment of the money supply to clear the money market at the prevailing interest rate and price

\footnotetext{
${ }^{5}$ Sargent and Wallace (1981) employ these assumptions about policy in their classic "Unpleasant Monetarist Arithmetic" example.
} 
level. The monetary expansion is given by $d M_{t}=d B_{t} /\left(B_{t} / M_{t}\right)$, making clear that the monetary accommodation varies inversely with the level of indebtedness. ${ }^{6}$

These exercises demonstrate that how a tax cut financed by nominal bond sales impacts inflation and the price level depends on assumptions about how current and future monetary and fiscal policies respond to the tax cut to be consistent with equilibrium.

\section{Background on Monetary and Fiscal Interactions}

The model in the previous section lays out the logic of how current and future macro policies interact to determine the equilibrium. Stationary analysis, however, can make it difficult to link the results to observed time series. It can also be informative to characterize policy behavior in terms of simple rules, rather than sequences of policy variables. For example, it is now popular to describe a central bank's policy of "leaning against the wind" as raising the policy interest rate instrument whenever the inflation rate exceeds the bank's target level [Taylor (1993)]. We turn now to an analysis using parametric families of policy rules that have received attention in previous research.

4.1. Setup. To the model in section 3 we append the following rules for monetary policy:

$$
i_{t}=\left(\frac{\pi_{t}}{\pi^{*}}\right)^{\alpha} \theta_{t}
$$

and for tax policy:

$$
\tau_{t}=\left(\frac{b_{t-1}}{b^{*}}\right)^{\gamma} \psi_{t},
$$

where $\pi^{*}$ and $b^{*}$ are target inflation and debt levels, $b_{t-1}=B_{t-1} / P_{t-1}$ is real debt at the end of period $t-1$, which is carried into period $t$, and $\theta$ and $\psi$ are mutually uncorrelated random variables with unit mean, possibly serially correlated, describing exogenous changes in monetary and tax policies. With this modification, the expectations operator $E_{t}$ is now taken with respect to $\Omega_{t}=\left\{\theta_{t-j}, \psi_{t-j}, j \geq 0\right\}$. Random policies shift the focus of fiscal finance away from average and toward marginal sources of revenues.

\footnotetext{
${ }^{6}$ This exercise corresponds to the fiscal theory of the price level as described by Leeper (1991), Sims (1994), and Woodford (1995). As Cochrane (2001) observes, the precise result discussed relies on government debt being sold at par. If it sold at a discount instead, the price of bonds may absorb some of the adjustment to equilibrium, offsetting some of the price level impacts.
} 
4.2. Equilibrium. Randomness coupled with policy rules makes the model analytically intractable, so analysis focuses on local dynamics in the neighborhood of the steady state when the policy shocks are identically zero and inflation and debt are at their target levels. Define the percentage deviation from steady state as $\hat{x}_{t} \equiv \ln x_{t}-\ln \bar{x}$, where $\bar{x}$ denotes steady state value. The model reduces to a system of two linear stochastic difference equations in inflation and real debt: ${ }^{7}$

$$
E_{t} \hat{\pi}_{t+1}=\alpha \hat{\pi}_{t}+\hat{\theta}_{t}
$$

and

$$
\hat{b}_{t}+\lambda_{1} \hat{\pi}_{t}-\left[\beta^{-1}-\gamma\left(\beta^{-1}-1\right)\right] \hat{b}_{t-1}+\lambda_{2} \hat{\pi}_{t-1}+\left[\beta^{-1}-1\right] \hat{\psi}_{t}+\lambda_{3} \hat{\theta}_{t}+\lambda_{4} \hat{\theta}_{t-1}=0,
$$

where

$$
\begin{array}{ll}
\lambda_{1}=\frac{\bar{m}}{b}(\alpha \varphi+1)+\beta^{-1} & \lambda_{3}=\frac{\bar{m}}{b} \varphi \\
\lambda_{2}=-\alpha\left[\frac{\bar{m}}{b} \varphi+\beta^{-1}\right] & \lambda_{4}=-\left[\frac{\bar{m}}{b} \varphi+\beta^{-1}\right] .
\end{array}
$$

$\varphi$ is the negative interest elasticity of money demand and $\bar{m} / \bar{b}$ is the steady state money-debt ratio. $^{8}$ Expression (21) is simplified by focusing on a steady state with no government spending $(\bar{g}=0)$ and a constant price level $(\bar{\pi}=1)$. The eigenvalues of (20) and (21) are $\alpha$ and $\beta^{-1}-\gamma\left(\beta^{-1}-1\right)$, and a unique saddle-path equilibrium requires (the modulus of) the two roots to lie on either side of 1 [Blanchard and Kahn (1980)]. We focus on two economically meaningful regions of the policy parameter space for which unique equilibria exist:

$$
\begin{aligned}
& \text { Region I: } \alpha>1 \text { and } \gamma>1 \\
& \text { Region II: } \alpha<1 \text { and } \gamma<1 \text {. }
\end{aligned}
$$

Policy impacts on inflation are qualitatively different across the two regions.

Policy behavior in the two regions is "active" or "passive," referring to the constraints a policy authority faces. An active authority pays no attention to the state of government debt and is free to set its control variable as it sees fit. Monetary policy is active in Region I and fiscal policy is active in Region II. A passive authority responds to government debt in a manner constrained by the equilibrium, which depends on

\footnotetext{
${ }^{7}$ Leeper (1991) contains a more complete derivation.

${ }^{8}$ To obtain (21), use the log-linear approximations of money demand $\hat{m}_{t}=-(1 / \chi)(\beta /(1-\beta)) \hat{\imath}_{t}$, where $1 / \chi$ is the intertemporal elasticity of substitution of real balances, and of the policy rules to obtain expressions for $\hat{\imath}_{t}$ and $\hat{\tau}_{t}$. Use those expressions in the linearized government budget constraint. We have also made the simplifying assumption that the steady state tax revenue to debt ratio, $\tau / b$, equals $\beta^{-1}-1$, which for typical values of $\beta$ is not an unreasonable assumption.
} 
POLICY INTERACTIONS AND THE PRICE LEVEL

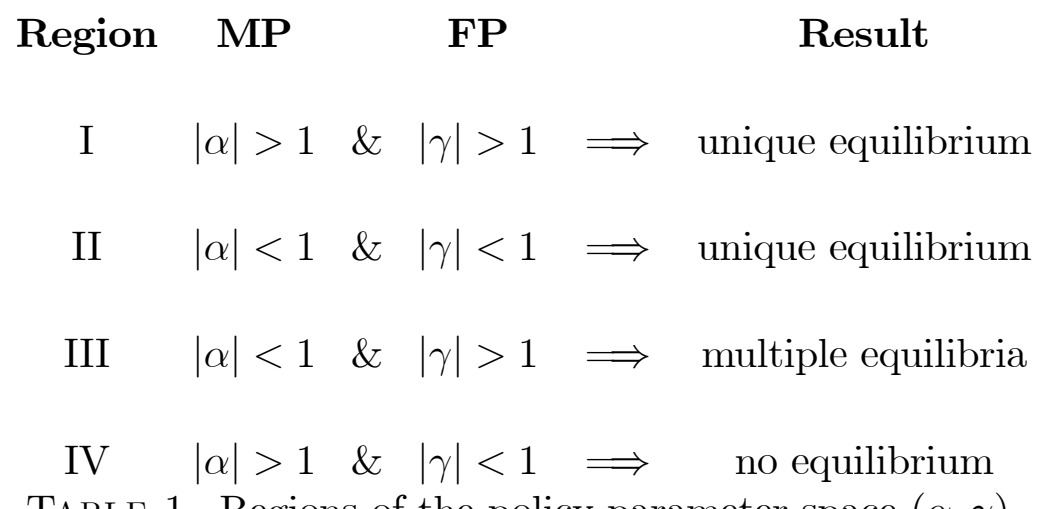

TABLE 1. Regions of the policy parameter space $(\alpha, \gamma)$.

private behavior and the active authority's actions. Fiscal policy is passive in Region I and monetary policy is passive in Region II.

For completeness, there are two additional regions to consider. Region III, in which both policies are passive and the eigenvalues are less than 1, implies the equilibrium is indeterminate, allowing for the possibility of self-fulfilling sunspot equilibria. In Region IV, where both policies are active and the eigenvalues exceed 1, neither policy authority is ensuring the government budget constraint is satisfied at every date. In this case, either no equilibrium exists, because the transversality condition for debt is violated, or no stationary equilibrium exists, because the debt-output ratio grows without bound (though the growth rate is less than $1 / \beta$ ). The policy parameter space is summarized in table 1.

4.3. Bond-Financed Tax Cut. An exogenous reduction in taxes is a negative realization of the shock to the tax rule, $\psi_{t}$. Policies considered in section 3.4 are reproduced under alternative settings of the two crucial policy parameters, $(\alpha, \gamma)$.

4.3.1. Ricardian equivalence. In Region I, monetary policy is active and responds to an increase in inflation by raising the nominal interest rate by enough to increase the real interest rate. Fiscal policy reacts passively to increases in government debt by raising future taxes sufficiently to service the new debt. Under these policies, tax disturbances do not influence equilibrium prices, interest rates, or real balances.

Equilibrium inflation is given by

$$
\hat{\pi}_{t}=-\frac{1}{\alpha} E_{t} \sum_{i=0}^{\infty}\left(\frac{1}{\alpha}\right)^{i} \hat{\theta}_{t+i}
$$

and the sequence for equilibrium real debt, $\left\{\hat{b}_{t}\right\}$, evolves according to the stable difference equation (20). Evidently, inflation - and money growth - is entirely a monetary 
phenomenon in the sense that it is independent of shocks to tax policy. Debt and taxes, on the other hand, respond to both monetary and tax disturbances. This result corresponds to Ricardian equivalence, the policy in section 3.4.1. This conventional monetarist outcome requires passive fiscal behavior.

4.3.2. The fiscal theory I. Fiscal policy is active in Region II and sets taxes independently of the state of government indebtedness. The central bank behaves passively, adjusting money growth and thereby controlling the nominal interest rate, to prevent government debt from following an unsustainable path. Constrained by fiscal financing needs, the central bank can no longer achieve any price level it desires and tax disturbances can be inflationary.

To reproduce the policy in section 3.4.3, consider the special case of a pegged nominal interest rate $(\alpha=0)$ and exogenous taxes $(\gamma=0)$. Also assume the policy shocks are serially uncorrelated. Gordon and Leeper (forthcoming) call this mix of exogenous taxes and a pegged nominal interest rate "the canonical fiscal theory of the price level exercise." Equilibrium inflation is

$$
\hat{\pi}_{t}=-\left(\frac{1-\beta}{\beta \frac{m}{b}+1}\right) \hat{\psi}_{t}-\frac{\frac{m}{b}}{\frac{m}{b}+\beta^{-1}}[\beta(1-\varphi)+\varphi] \hat{\theta}_{t}+\hat{\theta}_{t-1} .
$$

Note that the steady state level of government debt influences the responses of inflation to both monetary and fiscal policy changes. A tax cut (negative realization of $\psi$ ) raises inflation, with the elasticity of inflation with respect to taxes rising with the level of government debt. If monetary policy raises the nominal rate (positive realization of $\theta$ ), current inflation may rise or fall, depending on the interest elasticity of money demand. For elasticities ranging from inelastic to modest, current inflation falls, matching conventional notions that a higher nominal rate is "tighter" policy. But the Fisher relation kicks in, so the same increase in $i_{t}$ raises the expected inflation rate one-for-one.

As in section 3.4.3, fiscal disturbances are not permitted to change the real value of government debt. In equilibrium, real debt is

$$
\hat{b}_{t}=\beta \frac{m}{b}(1-\varphi) \hat{\theta}_{t},
$$

so i.i.d. tax changes leave debt unchanged, while open-market sales raise the level of debt. The higher debt carried into the future is serviced - and retired - by higher seigniorage revenues, raising future inflation.

In the equilibrium just presented, on average seigniorage revenues are zero because the steady state is one with a constant price level. On the margin, though, seigniorage is very important: without the appropriate (passive) adjustment in the money 
stock, there can be no equilibrium - government debt would follow an unsustainable explosive path and become worthless. Standard methods to evaluate if seigniorage is an "important" source of revenues, such as computing the time-average of seigniorage revenues as a share of GDP [King (1995)], may have nothing to say about its importance on the margin. There is reason to believe this point may be important in practice. Setting $\alpha=0$ implies the central bank does not adjust its interest rate instrument in the face of fiscal disturbances. Because exogenous changes in taxes, which correspond to realizations if $\psi$, are notoriously difficult to identify in data, it is also difficult to trace whether this kind of accommodation of fiscal policy occurs.

4.3.3. The fiscal theory II. For a variant of the canonical fiscal theory, suppose the central bank, instead of literally pegging the nominal rate, adjusts it less than onefor-one with inflation $(0<\alpha<1)$, while the fiscal authority continues to set taxes exogenously $(\gamma=0)$. Now tax cuts raise inflation and the nominal rate jointly. Higher $i$ raises expected inflation, which is rationalized by the passive increase in expected future money growth. Instead of the passive response of money growth occurring contemporaneously with the tax shock, as it does when $\alpha=0$, monetary policy's passive adjustment occurs gradually, raising both current and expected money creation. Although again this is not the usual monetization of deficits, the equilibrium exhibits the common view that deficits are monetized if and only if deficits predict, or Granger-cause, money growth [King and Plosser (1985)].

\section{The Fiscal Theory with Tax Distortions}

The model structure of sections 3 and 4-an endowment economy with lumpsum taxes - is useful for isolating the fiscal theory mechanism, which works through the demand for consumption goods. But the stylized structure makes it hard to connect the fiscal theory to the actual tax systems that the public finance literature studies. This section takes a step toward that literature by endogenizing output and considering a proportional income tax, introducing supply considerations into the analysis. ${ }^{9}$

5.1. Household and Government Budget Constraints. We begin by describing the equilibrium balance sheet of the representative household in a model with complete markets for contingent claims and fiat money. Production is constant returns to scale in labor inputs. We then analyze effects of tax policy on the equilibrium balance sheet of the household.

\footnotetext{
${ }^{9}$ Linnemann (2005) linearizes and examines a related setup. His method of analysis, however, loses some of the richness developed below.
} 
Preferences of the representative household are

$$
E_{0} \sum_{t=0}^{\infty} \beta^{t}\left[u\left(c_{t}, m_{t}\right)+v\left(1-h_{t}\right)\right], \quad 0<\beta<1,
$$

where the new variable, $h_{t}$, is the number of hours worked at period $t$ and $m_{t}=M_{t} / P_{t}$. The sequence of household budget constraints is given by

$$
c_{t}+m_{t}+E_{t}\left[Q_{t, t+1} \frac{B_{t, t+1}}{P_{t}}\right] \leq\left(1-\tau_{t}\right)\left(w_{t} h_{t}+\Phi_{t}\right)+\frac{B_{t-1, t}+M_{t-1}}{P_{t}},
$$

for $t \geq 0$, with $B_{-1,0}+M_{-1}>0$ given. $Q_{t, t+1}$ is the stochastic discount factor used to compute the nominal value at period $t$ of one dollar at period $t+1, w_{t}$ is the real wage rate at period $t, \Phi_{t}$ is real dividends, and $\tau_{t}$ is the income tax rate. $E_{t}\left[Q_{t, t+1} \frac{B_{t, t+1}}{P_{t}}\right]$ corresponds to the real value in period $t$ of nominal state contingent claims purchased by the household, where $B_{t, t+1}$ is the number of nominal state contingent bonds paying one dollar in a given state in period $t+1$ and nothing in other states. The (gross) nominal interest rate at period $t$, denoted by $1+i_{t}$, is

$$
1+i_{t}=\frac{1}{E_{t}\left[Q_{t, t+1}\right]}
$$

Let $q_{t, t+1}$ denote the stochastic discount factor used to compute the real value at period $t$ of one unit of consumption good at period $t+1$. Then

$$
Q_{t, t+1}=q_{t, t+1} \frac{P_{t}}{P_{t+1}} .
$$

The period budget constraints can now be rewritten as

$$
c_{t}+\frac{i_{t}}{1+_{t}} m_{t}+E_{t}\left[q_{t, t+1} a_{t+1}\right] \leq\left(1-\tau_{t}\right)\left(w_{t} h_{t}+\Phi_{t}\right)+a_{t},
$$

for $t \geq 0$. $a_{t}$ denotes the real value at period $t$ of nominal assets carried from period $t-1$ :

$$
a_{t}=\frac{B_{t-1, t}+M_{t-1}}{P_{t}}
$$

Successive forward iteration of the budget constraint leads to the present-value budget constraint at period 0 :

$$
E_{0} \sum_{t=0}^{\infty} q_{t}\left[c_{t}+\frac{i_{t}}{1+i_{t}} m_{t}-\left(1-\tau_{t}\right)\left(w_{t} h_{t}+\Phi_{t}\right)\right] \leq a_{0}
$$

with $\lim _{t \rightarrow \infty} E_{0}\left[q_{t} a_{t}\right]=0$, where $q_{t}$ is the stochastic discount factor used for computing the real value at period 0 of one unit of consumption goods at period $t$ and $q_{0}=1$. The first-order conditions for consumption and real money balances are

$$
\beta^{t} u_{c}\left(c_{t}, m_{t}\right)=\lambda q_{t}
$$




$$
\beta^{t} u_{m}\left(c_{t}, m_{t}\right)=\lambda q_{t}\left(\frac{i_{t}}{1+i_{t}}\right)
$$

where $\lambda=u_{c}\left(c_{0}, m_{0}\right)$ is the Lagrange multiplier of the present value budget constraint, $u_{c}\left(c_{t}, m_{t}\right)$ is the marginal utility of consumption, and $u_{m}\left(c_{t}, m_{t}\right)$ is the marginal utility of real money balances. The first-order condition for labor supply is

$$
\frac{v^{\prime}\left(1-h_{t}\right)}{u_{c}\left(c_{t}, m_{t}\right)}=\left(1-\tau_{t}\right) w_{t} .
$$

Next we compute the equilibrium real value of the initial nominal assets of the representative household. Substitute the first-order conditions for consumption and real money balances along with $\Phi_{t}=y_{t}-w_{t} h_{t}$ into the present-value budget constraint to yield

$$
\frac{E_{0} \sum_{t=0}^{\infty} \beta^{t}\left[u_{c}\left(c_{t}, m_{t}\right) c_{t}+u_{m}\left(c_{t}, m_{t}\right) m_{t}-\left(1-\tau_{t}\right) y_{t} u_{c}\left(c_{t}, m_{t}\right)\right]}{u_{c}\left(c_{0}, m_{0}\right)}=a_{0}
$$

where we used the fact that $q_{t}=\beta^{t} u_{c}\left(c_{t}, m_{t}\right) / u_{c}\left(c_{0}, m_{0}\right) .{ }^{10}$ The left-hand side of this equation is written entirely in terms of allocations. When allocations are uniquely determined, we have a unique real value of nominal assets,

$$
a_{0}=\frac{B_{-1,0}+M_{-1}}{P_{0}} .
$$

Because $B_{-1,0}+M_{-1}>0$ are the pre-determined nominal assets with which the household begins life, if the equilibrium present value constraint is binding, then when a set of fiscal and monetary policies generate a determinate equilibrium allocation $\left\{c_{t}, y_{t}, m_{t}\right\}_{t=0}^{\infty}$, the equilibrium price level in the initial period also has a unique finite value. $^{11}$

Under rational expectations, $a_{0}$ is the real value of initial nominal assets, which is known to the household when it solves its optimization problem. This reasoning implies that the present-value condition in (37) is an equilibrium balance sheet relation, where the left-hand side of the constraint is the present value of the household's liabilities - debt and net worth - at period 0 .

An equilibrium condition analogous to (37), but involving policy variables, can be derived from (37). Substituting the aggregate market clearing condition, $y_{t}=c_{t}+g_{t}$,

\footnotetext{
${ }^{10}$ Expression (37) is closely related to the "implementability condition" that serves as a constraint in the primal approach to the Ramsey problem of optimal taxation [Jones, Manuelli, and Rossi (1993)].

${ }^{11}$ Note that the initial condition on asset is specified in terms of nominal values. The link to the initial price level does not hold if $a_{0}$ itself is an initial condition.
} 
into (37),

$$
E_{0} \sum_{t=0}^{\infty} \beta^{t} \frac{u_{c}\left(c_{t}, m_{t}\right)}{u_{c}\left(c_{0}, m_{0}\right)}\left[\left(\tau_{t} y_{t}-g_{t}\right)+\frac{u_{m}\left(c_{t}, m_{t}\right)}{u_{c}\left(c_{t}, m_{t}\right)} m_{t}\right]=a_{0} .
$$

Recalling that $q_{t}=\beta^{t} \frac{u_{c}\left(c_{t}, m_{t}\right)}{u_{c}\left(c_{0}, m_{0}\right)}$ and substituting equilibrium real money balances into this equation yields the analogous present value equilibrium condition:

$$
E_{0} \sum_{t=0}^{\infty} q_{t}\left[\tau_{t} y_{t}-g_{t}+\frac{i_{t}}{1+i_{t}} m_{t}\right]=a_{0}
$$

The first-term in the left-hand side is the expected discounted present value of primary surpluses and the second term is the expected present value of seigniorage revenue from money creation. Evidently, although this expression is frequently referred to as the government's intertemporal budget "constraint," it is also an equilibrium condition. As an equilibrium condition, it plays a role in determining some or all of the endogenous variables that enter it. ${ }^{12}$

5.2. A Price-Theoretic View of the Fiscal Theory. To study the impacts of a tax change in the general equilibrium model of section 5.1, it is instructive to follow the public finance literature to construct a decomposition of the impacts in the spirit of Slutsky $(1915,1952)$ and Hicks $(1939) .{ }^{13}$ To do this in an environment in which the fiscal theory may be operative, we must extend the usual decomposition to include a third effect induced by the fiscal theory mechanism. The fiscal theory works through a type of wealth effect that arises when change in the price level revalues nominal government assets in households' portfolios. To the usual substitution and wealth effects associated with tax changes, we add a "revaluation effect." The conventional wealth effect stems from a change in the expected present-value of current and future labor income flows.

It is convenient to re-express the household's budget constraint in terms of maximum income. In period $t$, maximum income is defined as the sum of dividend income

\footnotetext{
${ }^{12}$ Whether (40) should be treated as a constraint facing the government or as an equilibrium condition of the model lies at the heart of Buiter's (2002) critique of the fiscal theory. He argues that, in parallel to household behavior, government should be constrained to choose sequences of policy variables that satisfy (40) for all positive price sequences, $\left\{P_{t}\right\}, t \geq 0$. We treat the consolidated monetary and fiscal authorities as choosing sequences of policy variables to be consistent with (40) and other conditions. For example, the government cannot choose $g_{t}>y_{t}$, as that would imply $c_{t}<0$, which is inconsistent with equilibrium. But to our knowledge, $c_{t}+g_{t}=y_{t}$ is not referred to as a government budget constraint.

${ }^{13} \mathrm{King}$ (1991) decomposes the effects of changes in government consumption into substitution and wealth effects in a linearized neo-classical growth model.
} 
and the maximum labor income households could earn if they worked the full amount of their (unit) time endowment:

$$
y_{t}^{F}=\left(1-\tau_{t}\right) w_{t}+\Phi_{t}
$$

where $y_{t}^{F}$ denotes the maximum income at period $t .{ }^{14}$ Households take as given their maximum income when they choose plans for their consumption, real money balances, and leisure. We think of maximum income as an endowment of income, which the household takes as given and uses to purchase consumption, real money balances, and leisure. Maximum income facilitates capturing the effects of tax changes on the opportunity set of leisure when leisure is a choice variable. The period budget constraints can be rewritten as

$$
c_{t}+\frac{i_{t}}{1+i_{t}} m_{t}+\left(1-\tau_{t}\right) w_{t}\left(1-h_{t}\right)+E_{t}\left[q_{t, t+1} a_{t+1}\right] \leq y_{t}^{F}+a_{t},
$$

for $t \geq 0$. Successive forward iteration of (42) leads to the following present-value budget constraint at period 0 :

$$
E_{0} \sum_{t=0}^{\infty} q_{t}\left[c_{t}+\frac{i_{t}}{1+i_{t}} m_{t}+\left(1-\tau_{t}\right) w_{t}\left(1-h_{t}\right)\right] \leq a_{0}+v_{0}
$$

with $\lim _{t \rightarrow \infty} E_{0}\left[q_{t} a_{t}\right]=0, \lim _{t \rightarrow \infty} E_{0}\left[q_{t} y_{t}^{F}\right]=0$. $v_{0}$ denotes the expected present-value of full income flows from period 0 onward:

$$
v_{0}=E_{0} \sum_{t=0}^{\infty}\left[q_{t} y_{t}^{F}\right]
$$

We restrict analysis to equilibria in which $v_{0}$ and $a_{0}$ have positive and finite values. A competitive household takes $a_{0}$ and $v_{0}$ parametrically.

The first-order conditions, (34)-(36), and the budget constraint imply demand functions for consumption and real money balances and a supply function for labor. Substituting the optimality conditions into the household's budget constraint, the Lagrange multiplier of the budget constraint is

$$
\lambda=\frac{e_{0}}{a_{0}+v_{0}}
$$

where $e_{0}$ is the expected present-value of expenditures (including leisure) evaluated using the household's optimality conditions:

$$
e_{0}=E_{0} \sum_{t=0}^{\infty} \beta^{t}\left[u_{c}\left(c_{t}, m_{t}\right) c_{t}+u_{m}\left(c_{t}, m_{t}\right) m_{t}+v^{\prime}\left(1-h_{t}\right)\left(1-h_{t}\right)\right] .
$$

\footnotetext{
${ }^{14}$ Becker (1965) refers to this as "full income." To avoid confusion with macroeconomic concepts like "full employment level of output," we also call it "maximum income."
} 
Because $\lambda$ is the shadow price of wealth, (45) implies that an increase in wealth, $a_{0}+v_{0}$, decreases the shadow price of wealth, while an increase in expenditures, $e_{0}$, increases it. Substituting (45) into (34) and (35), we have the following demand functions for consumption and real money balances:

$$
\begin{aligned}
c_{t} & =c\left(\frac{q_{t}}{\beta^{t}}, \frac{i_{t}}{1+i_{t}}, \frac{a_{0}+v_{0}}{e_{0}}\right), \\
m_{t} & =m\left(\frac{q_{t}}{\beta^{t}}, \frac{i_{t}}{1+i_{t}}, \frac{a_{0}+v_{0}}{e_{0}}\right) .
\end{aligned}
$$

Substituting these demand functions into (36) yields the labor supply function:

$$
h_{t}=h\left(\left(1-\tau_{t}\right) w_{t}, \frac{q_{t}}{\beta^{t}}, \frac{i_{t}}{1+i_{t}}, \frac{a_{0}+v_{0}}{e_{0}}\right) \text {. }
$$

5.2.1. The revaluation effect of distorting tax policy. There is an important distinction between the revaluation effect of tax policy and the conventional wealth effect of tax policy in the public finance literature.

The key mechanism through which the fiscal theory of the price level works is the effect of fiscal policy on the price level at period $0 .{ }^{15}$ In other words, the fiscal theory of the price level asserts that fiscal policy can determine a unique value of the equilibrium price level at period 0 , so long as monetary policy is not also determining the price level. ${ }^{16}$ The revaluation effect of tax policy works through its effect on the real value of the initial nominal assets, denoted by $a_{0}$. More explicitly, since households are identical in our economy, it follows from the definition of $a_{0}$ that the equilibrium real value of the initial nominal assets, denoted by $a_{0}^{e}$, is

$$
a_{0}^{e}=\frac{B_{-1,0}+M_{-1}}{P_{0}} .
$$

Under the fiscal theory of price level, tax policy can determine a unique equilibrium value of $P_{0}$ by uniquely determining $a_{0}^{e}$.

The revaluation effect needs to be distinguished from the conventional wealth effect that is analyzed in the public finance literature. Suppose, for example, that initial nominal assets are zero, i.e., $B_{-1,0}+M_{-1}=0$. Even in this case, when the revaluation effect on $P_{0}$ is always zero, we can see from equations (47), (48), and (49) that the conventional wealth effect of tax policy can affect consumption, real money balances

\footnotetext{
${ }^{15}$ The focus on the date 0 price level stems from the presentation's use of an Arrow-Debreu structure with complete markets in dated contingent claims all traded at time 0 . In a stochastic model with a sequential-trading structure, the fiscal theory determines the price level at each date $t$.

${ }^{16}$ In terms of the language in section 4 , the fiscal theory of the price level is operative when fiscal policy is active and monetary policy is passive.
} 
and labor supply through its effects on $v_{0}$ and $e_{0}$. When $B_{-1,0}+M_{-1}>0$, the revaluation effect operates independently of the conventional wealth effect.

Of course, changes in taxes can affect the price level even in environments where the fiscal theory is not operative. When monetary policy is active and fiscal policy adjusts passively to ensure the equilibrium conditions (equations (37) and (40), among others) are always satisfied, a change in tax policy can affect the equilibrium price level solely through its effects on aggregate demand and supply. For example, suppose that the government raises the income tax rate at period $0, \tau_{0}$. The substitution effect of the temporary rise in income tax rate decreases the labor supply and the wealth effect raises it at the same time. The final impact on labor supply and the price level depends on whether the wealth effect or the substitution effect dominates.

In this environment, the resulting change in the price level generates a revaluation effect which, through passive tax policy, imposes restrictions on the sequence of expected future tax rates, $\left\{\tau_{t}\right\}_{t=1}^{\infty}$, necessary for equilibrium. In contrast, under the fiscal theory, fiscal policy is active and the entire sequence of tax rates, $\left\{\tau_{t}\right\}_{t=0}^{\infty}$, is exogenous. Active fiscal behavior, together with passive monetary policy, imply that $P_{0}$ (and hence $a_{0}$ ) must adjust to ensure that equations (37) and (40), and conditions for equilibrium are satisfied.

5.2.2. Deriving substitution, wealth, and revaluation effects. We define substitution, wealth, and revaluation effects generally, without any specific assumptions about fiscal or monetary policy behavior. Suppose that the labor income tax rate process changes exogenously at period 0 from $\left\{\tau_{t}^{*}\right\}_{t=0}^{\infty}$ to $\left\{\tau_{t}^{\dagger}\right\}_{t=0}^{\infty}$. The optimization problem of the household under tax regime '*' can be written as

$$
\max _{\left\{c_{t}, m_{t}, h_{t}\right\}_{t=0}^{\infty}} E_{t} \sum_{t=0}^{\infty} \beta^{t}\left[u\left(c_{t}, m_{t}\right)+v\left(1-h_{t}\right)\right]
$$

subject to

$$
E_{0} \sum_{t=0}^{\infty} q_{t}\left[c_{t}+\frac{i_{t}}{1+i_{t}} m_{t}+\left(1-\tau_{t}^{*}\right) w_{t}\left(1-h_{t}\right)\right] \leq a_{0}+v_{0} .
$$

On the other hand, the optimization problem of the household under tax policy regime ' $\dagger$ ' can be written as

$$
\max _{\left\{c t, m_{t}, h_{t}\right\}_{t=0}^{\infty}} E_{0} \sum_{t=0}^{\infty} \beta^{t}\left[u\left(c_{t}, m_{t}\right)+v\left(1-h_{t}\right)\right]
$$

subject to

$$
E_{0} \sum_{t=0}^{\infty} q_{t}\left[c_{t}+\frac{i_{t}}{1+i_{t}} m_{t}+\left(1-\tau_{t}^{\dagger}\right) w_{t}\left(1-h_{t}\right)\right] \leq a_{0}+v_{0}
$$


We assume that the tax policy regime ' $*$ ' yields the sequence of equilibrium quantities and prices $\left\{c_{t}^{*}, m_{t}^{*}, h_{t}^{*}, w_{t}^{*}, a_{t}^{*}, v_{t}^{*}, e_{t}^{*}, P_{t}^{*}, q_{t}^{*}, R_{t}^{*}, \Phi_{t}^{*}\right\}_{t=0}^{\infty}$. The sequence of equilibrium quantities and prices $\left\{c_{t}^{\dagger}, h_{t}^{\dagger}, w_{t}^{\dagger}, a_{t}^{\dagger}, v_{t}^{\dagger}, e_{t}^{\dagger}, P_{t}^{\dagger}, q_{t}^{\dagger}, R_{t}^{\dagger}, \Phi_{t}^{\dagger}\right\}_{t=0}^{\infty}$ corresponds to the tax regime ' $†$ '.

To compute the substitution effect of the change in tax policy, we use a lump-sum transfer at period $t$, denoted by $T_{0}^{s}$, through which the household can achieve the same utility level that the household would have obtained under the tax policy '*', even though it optimizes under the price system of the tax policy ' $\dagger$ '. Specifically, consider the following optimization problem of the household:

$$
\max _{\left\{c_{t}, m_{t}, h_{t}\right\}_{t=0}^{\infty}} E_{0} \sum_{t=0}^{\infty} \beta^{t}\left[u\left(c_{t}, m_{t}\right)+v\left(1-h_{t}\right)\right]
$$

subject to

$$
E_{0} \sum_{t=0}^{\infty} q_{t}^{\dagger}\left[c_{t}+\frac{i_{t}^{\dagger}}{1+i_{t}^{\dagger}} m_{t}+\left(1-\tau_{t}^{\dagger}\right) w_{t}^{\dagger}\left(1-h_{t}\right)\right] \leq a_{0}^{\dagger}+v_{0}^{\dagger}+T_{0}^{s} .
$$

Prices in the budget constraint, (56), are constrained to be equilibrium prices under tax policy regime ' $†$ '. This ensures that the budget line of this problem is tangent to the household's indifference surface under tax regime ' $\nmid$ '. In addition, the lumpsum transfer $T_{0}^{s}$ guarantees that the utility level that the household obtains from the optimization problem (51)-(52) is the same as the one that comes from (55)-(56). Hence, our decomposition is consistent with a Hicksian decomposition of the tax policy change.

Recall that a competitive household takes $a_{0}$ and $v_{0}$ parametrically. To capture the revaluation effect, confront the household with two counterfactual optimization problems. First, if households assume that revaluation of assets does not result from the tax change, so that their assets have value $a_{0}=a_{0}^{*}$ under the tax regime ' $\dagger$ ', their optimization problem can be written as

$$
\max _{\left\{c_{t}, m_{t}, h_{t}\right\}_{t=0}^{\infty}} E_{0} \sum_{t=0}^{\infty} \beta^{t}\left[u\left(c_{t}, m_{t}\right)+v\left(1-h_{t}\right)\right]
$$

subject to

$$
E_{0} \sum_{t=0}^{\infty} q_{t}^{\dagger}\left[c_{t}+\frac{i_{t}^{\dagger}}{1+i_{t}^{\dagger}} m_{t}+\left(1-\tau_{t}^{\dagger}\right) w_{t}^{\dagger}\left(1-h_{t}\right)\right] \leq a_{0}^{*}+v_{0}^{\dagger}
$$

Next, we introduce a lump-sum transfer, denoted by $T_{0}^{w}$, to adjust the level of utility that can be derived when revaluation of assets arises. Specifically, consider the 
optimization problem:

$$
\max _{\left\{c_{t}, m_{t}, h_{t}\right\}_{t=0}^{\infty}} E_{0} \sum_{t=0}^{\infty} \beta^{t}\left[u\left(c_{t}, m_{t}\right)+v\left(1-h_{t}\right)\right]
$$

subject to

$$
E_{0} \sum_{t=0}^{\infty} q_{t}^{\dagger}\left[c_{t}+\frac{i_{t}^{\dagger}}{1+i_{t}^{\dagger}} m_{t}+\left(1-\tau_{t}^{\dagger}\right) w_{t}^{\dagger}\left(1-h_{t}\right)\right] \leq a_{0}^{\dagger}+v_{0}^{\dagger}+T_{0}^{w} .
$$

The lump-sum transfer $T_{0}^{w}$ permits the optimization problems (59)-(60) and (57)-(58) to achieve the same level of utility. ${ }^{17}$

The total effect corresponds to the change in the consumer's decision between the two optimization problems (51)-(52) and (53)-(54). The substitution effect is the change in the consumer's decision between the two optimization problems (51)-(52) and (55)-(56). The revaluation effect is associated with the change in the consumer's decision between the two optimization problems (57)-(58) and (59)-(60). We compute the conventional wealth effect by subtracting the sum of the substitution and revaluation effects from the total effect.

The total effect of a tax change on consumption can be expressed in terms of substitution, wealth, and revaluation effects using the consumption demand functions derived from the optimization problems above. Denote the consumption demand functions under tax regimes $*$ and $\dagger$ by

$$
c_{t}^{*}=c\left(\frac{q_{t}^{*}}{\beta^{t}}, \frac{i_{t}^{*}}{1+i_{t}^{*}}, \frac{a_{0}^{*}+v_{0}^{*}}{e_{0}^{*}}\right) ; c_{t}^{\dagger}=c\left(\frac{q_{t}^{\dagger}}{\beta^{t}}, \frac{i_{t}^{\dagger}}{1+i_{t}^{\dagger}}, \frac{a_{0}^{\dagger}+v_{0}^{\dagger}}{e_{0}^{\dagger}}\right) .
$$

Consumption demand under optimization problem (55)-(56) is

$$
\left.c_{t}^{\dagger}\right|_{u_{0}=u_{0}^{*}}=c\left(\frac{q_{t}^{\dagger}}{\beta^{t}}, \frac{i_{t}^{\dagger}}{1+i_{t}^{\dagger}}, \frac{a_{0}^{*}+v_{0}^{*}+T_{0}^{s}}{\left.e_{0}^{\dagger}\right|_{u_{0}=u_{0}^{*}}}\right),
$$

where $\left.c_{t}^{\dagger}\right|_{u_{0}=u_{0}^{*}}$ is the level of planned consumption under tax policy $\dagger$, but holding the level of lifetime utility fixed at $u_{0}^{*}$, where $u_{0}^{*}$ is the level of lifetime utility under tax policy '*'. Problem (59)-(60) yields the consumption demand function:

$$
\left.c_{t}^{\dagger}\right|_{u_{0}=u_{0}^{\dagger}, a_{0}=a_{0}^{*}}=c\left(\frac{q_{t}^{\dagger}}{\beta^{t}}, \frac{i_{t}^{\dagger}}{1+i_{t}^{\dagger}}, \frac{a_{0}^{\dagger}+v_{0}^{\dagger}+T_{0}^{w}}{\left.e_{0}^{\dagger}\right|_{u_{0}=u_{0}^{\dagger}, a_{0}=a_{0}^{*}}}\right) .
$$

where $\left.c_{t}^{\dagger}\right|_{u_{0}=u_{0}^{\dagger}, a_{0}=a_{0}^{*}}$ is the level of planned consumption without revaluation of assets under tax policy ' $\nmid$ ', but holding the level of lifetime utility fixed at $u_{0}^{\dagger}$, where $u_{0}^{\dagger}$ is

\footnotetext{
${ }^{17}$ Note that whereas the transfer $T_{0}^{s}$ is in real income, the transfer $T_{0}^{w}$ is in nominal assets, so $T_{0}^{w}$ is the real value of asset transfers.
} 
the level of lifetime utility under tax policy ' $\nmid$ '. We now define the total effect of a tax change on planned consumption as the logarithmic difference between the planned consumption levels under the two tax regimes. This total effect can be decomposed into the sum of substitution, wealth, and revaluation effects:

$$
\begin{array}{cccc}
\log \left(\frac{c_{t}^{\dagger}}{c_{t}^{*}}\right)= & \log \left(\frac{\left.c_{t}^{\dagger}\right|_{u_{0}=u_{0}^{*}}}{c_{t}^{*}}\right)+\log \left(\frac{\left.c_{t}^{\dagger}\right|_{u_{0}=u_{0}^{\dagger}, a_{0}=a_{0}^{*}}}{\left.c_{t}^{\dagger}\right|_{u_{0}=u_{0}^{*}}}\right)+\log \left(\frac{c_{t}^{\dagger}}{\left.c_{t}^{\dagger}\right|_{u_{0}=u_{0}^{\dagger}, a_{0}=a_{0}^{*}}}\right) . \\
\text { total } & \text { substitution } & \text { wealth } & \text { revaluation } \\
\text { effect } & \text { effect } & \text { effect } & \text { effect }
\end{array}
$$

This decomposition offers a new approach to isolating the fiscal theory mechanism that is fully compatible with conventional price theory. ${ }^{18}$

5.3. An Example Economy. We present an analytical solution to a simple dynamic general equilibrium model as an example of our extended Slutsky-Hicks decomposition. We restrict preferences to be logarithmic over consumption, real money balances, and labor supply with additive separability, and technology to be linear. Then the value functions are additively separable between wealth terms and price terms. Appendix A demonstrates that when the elasticity of inter-temporal substitution deviates from one, value functions are no longer additively separable between wealth and prices.

5.3.1. Deriving the value function. In our example, the preferences of households are represented by the utility function:

$$
u\left(c_{t}, m_{t}\right)+v\left(1-h_{t}\right)=\log c_{t}+\log m_{t}+\log \left(1-h_{t}\right) .
$$

The expected present value of expenditures, defined in (46), is

$$
e_{0}=\frac{3}{1-\beta}
$$

Substituting (65) into optimization conditions (34), (35), and (36), we can express consumption, real money balances, and labor supply in terms of prices and wealth as shown in (47), (48), and (49). More explicitly, the consumption demand function at period $t$ can be written as

$$
c_{t}=\left(\frac{1-\beta}{3}\right)\left(\frac{\beta^{t}}{q_{t}}\right)\left(a_{0}+v_{0}\right) .
$$

\footnotetext{
${ }^{18}$ There is no unique way to define the decomposition. We use the price system of tax regime ' $\dagger$ ' to evaluate the consumption change due to the revaluation effect. Alternatively, one may use the price system of tax regime ' $*$ ' to evaluate the consumption change due to the revaluation effect.
} 
Consumption demand has elasticities of unity with respect to wealth and -1 with respect to intertemporal relative prices. The demand for real money balances is

$$
m_{t}=\left(\frac{1-\beta}{3}\right) \frac{1+i_{t}}{i_{t}}\left(\frac{\beta^{t}}{q_{t}}\right)\left(a_{0}+v_{0}\right)
$$

while labor supply function is

$$
h_{t}=1-\left(\frac{1-\beta}{3}\right)\left(\frac{\beta^{t}}{\left(1-\tau_{t}\right) w_{t} q_{t}}\right)\left(a_{0}+v_{0}\right) .
$$

Substituting (67)-(69) into (65) for each $t \geq 0$ and summing from period 0 onward, the expected discounted sum of instantaneous utilities evaluated at the consumer's optimum can be written as

$$
u_{0}=\frac{3}{1-\beta} \log \left(a_{0}+v_{0}\right)+E_{0} \sum_{t=0}^{\infty} \beta^{t} \gamma_{t}+\frac{3}{1-\beta} \log \frac{1-\beta}{3},
$$

where $u_{0}$ denotes the optimized level of the household's lifetime utility at period 0 and $\gamma_{t}$ is defined as

$$
\gamma_{t}=3\left(t \log \beta-\log q_{t}\right)+\log \frac{1+i_{t}}{i_{t}}-\left[\log \left(1-\tau_{t}\right)+\log w_{t}\right]
$$

5.3.2. Computing substitution, wealth, and revaluation effects. To compute substitution, wealth, and revaluation effects, we assume that households face an exogenous regime change in income tax policy from ' $*$ ' to ' $\uparrow$ ', as we did in the previous section. Given logarithmic, additively separable preferences for consumption, the ratio of consumption levels under the two tax regimes is given by

$$
\frac{c_{t}^{\dagger}}{c_{t}^{*}}=\left(\frac{q_{t}^{*}}{q_{t}^{\dagger}}\right)\left(\frac{a_{0}^{\dagger}+v_{0}^{\dagger}}{a_{0}^{*}+v_{0}^{*}}\right) .
$$

We now compute the revaluation effect of tax change. First, we compute the size of lump-sum tax $T_{0}^{s}$ for the example economy. The value function from optimization problem (51)-(52) is

$$
u_{0}^{*}=\frac{3}{1-\beta} \log \left(a_{0}^{*}+v_{0}^{*}\right)+E_{0} \sum_{t=0}^{\infty} \beta^{t} \gamma_{t}^{*}+\frac{3}{1-\beta} \log \frac{1-\beta}{3},
$$

while the value function from the optimization problem (55)-(56) is

$$
\left.u_{0}^{\dagger}\right|_{u_{0}=u_{0}^{*}}=\frac{3}{1-\beta} \log \left(a_{0}^{\dagger}+v_{0}^{\dagger}+T_{0}^{s}\right)+E_{0} \sum_{t=0}^{\infty} \beta^{t} \gamma_{t}^{\dagger}+\frac{3}{1-\beta} \log \frac{1-\beta}{3} .
$$


Since the lump-sum transfer $T_{0}^{s}$ guarantees that $u_{0}^{*}=\left.u_{0}^{\dagger}\right|_{u_{0}=u_{0}^{*}}$, it follows from (73) and (74) that the lump-sum transfer satisfies

$$
T_{0}^{s}=\left(a_{0}^{*}+v_{0}^{*}\right) \exp \left[\frac{1-\beta}{3} E_{0} \sum_{t=0}^{\infty} \beta^{t}\left(\gamma_{t}^{*}-\gamma_{t}^{\dagger}\right)\right]-\left(a_{0}^{\dagger}+v_{0}^{\dagger}\right)
$$

In addition, the optimization problem (55)-(56) yields a compensated consumption demand function of the form:

$$
\left.c_{t}^{\dagger}\right|_{u_{0}=u_{0}^{*}}=\left(\frac{1-\beta}{3}\right)\left(\frac{\beta^{t}}{q_{t}^{\dagger}}\right)\left(a_{0}^{\dagger}+v_{0}^{\dagger}+T_{0}^{s}\right),
$$

The substitution effect can be therefore written as

$$
\frac{\left.c_{t}^{\dagger}\right|_{u_{0}=u_{0}^{*}}}{c_{t}^{*}}=\left(\frac{q_{t}^{*}}{q_{t}^{\dagger}}\right) \frac{a_{0}^{\dagger}+v_{0}^{\dagger}+T_{0}^{s}}{a_{0}^{*}+v_{0}^{*}} .
$$

Note that the value function from the optimization problem (57)-(58) is

$$
\left.\bar{u}_{0}^{\dagger}\right|_{u_{0}=u_{0}^{\dagger}}=\frac{3}{1-\beta} \log \left(a_{0}^{*}+v_{0}^{\dagger}\right)+E_{0} \sum_{t=0}^{\infty} \beta^{t} \gamma_{t}^{\dagger}+\frac{3}{1-\beta} \log \frac{1-\beta}{3},
$$

while the value function from the optimization problem (59)-(60) is

$$
\left.u_{0}^{\dagger}\right|_{u_{0}=u_{0}^{\dagger}}=\frac{3}{1-\beta} \log \left(a_{0}^{\dagger}+v_{0}^{\dagger}+T_{0}^{w}\right)+E_{0} \sum_{t=0}^{\infty} \beta^{t} \gamma_{t}^{\dagger}+\frac{3}{1-\beta} \log \frac{1-\beta}{3} .
$$

Since the lump-sum transfer $T_{0}^{w}$ leads to $\left.\bar{u}_{0}^{\dagger}\right|_{u_{0}=u_{0}^{\dagger}}=\left.u_{0}^{\dagger}\right|_{u_{0}=u_{0}^{\dagger}}$, we can use equations (78) and (79) to set the size of the lump-sum transfer:

$$
T_{0}^{w}=a_{0}^{*}-a_{0}^{\dagger}
$$

The wealth effect can be then written as

$$
\frac{\left.c_{t}^{\dagger}\right|_{u_{0}=u_{0}^{\dagger}, a_{0}=a_{0}^{*}}}{\left.c_{t}^{\dagger}\right|_{u_{0}=u_{0}^{*}}}=\frac{a_{0}^{\dagger}+v_{0}^{\dagger}+T_{0}^{w}}{a_{0}^{\dagger}+v_{0}^{\dagger}+T_{0}^{s}}
$$

The revaluation effect is

$$
\frac{c_{t}^{\dagger}}{\left.c_{t}^{\dagger}\right|_{u_{0}=u_{0}^{\dagger}, a_{0}=a_{0}^{*}}}=\frac{a_{0}^{\dagger}+v_{0}^{\dagger}}{a_{0}^{\dagger}+v_{0}^{\dagger}+T_{0}^{w}}
$$

Consequently, we can find that if revaluation of initial nominal assets results from a change in tax policy, it can have impact on planned consumption demands through the asset component of wealth. 
5.4. Revaluation Effect: Active Fiscal and Passive Monetary Policies. For the fiscal theory mechanism to be operative, with fiscal policy determining the price level, it must be the case that monetary policy is passive in the sense that the central bank ensures that an equilibrium exists when tax policy is active. One simple example of passive monetary policy is a nominal interest rate peg. Treating the sequence of tax rates as exogenous makes fiscal policy active. This section solves for the general equilibrium when tax policy changes from one exogenous sequence of tax rates to another, while monetary policy stands ready to buy and sell reserves in whatever quantity is necessary to hold the nominal interest rate fixed.

Suppose that the central bank maintains a constant nominal interest rate

$$
\beta\left(1+i_{t}\right)=1
$$

for $t \geq 0$.

5.4.1. The case of lump-sum taxes. Before tackling the more complicated case of distorting taxes, it is instructive to construct a Slutsky-Hicks decomposition for the simpler case of lump-sum taxes. To do this, we set $\tau_{t}=0$ for all $t$ and modify full income by subtracting the lump-sum tax, $z_{t}$ :

$$
y_{t}^{F}=w_{t}+\Phi_{t}-z_{t},
$$

so the household's period budget constraint becomes

$$
c_{t}+\frac{i_{t}}{1+i_{t}} m_{t}+w_{t}\left(1-h_{t}\right)+E_{t}\left[q_{t, t+1} a_{t+1}\right] \leq y_{t}^{F}+a_{t}
$$

With logarithmic preferences over $c, m$, and $1-h$, and a linear production technology, $y_{t}=h_{t}$, the expected present-value at period 0 of maximum income flows is given by

$$
v_{0}=E_{0}\left[\sum_{t=0}^{\infty} q_{t}\left(w_{t}-z_{t}\right)\right] .
$$

Utility maximization implies that labor supply satisfies

$$
\frac{c_{t}}{1-h_{t}}=w_{t}
$$

Setting $c_{t}=\left(1-s^{g}\right) y_{t}$ to clear the goods market and $h_{t}=y_{t}$ yields

$$
y_{t}=\frac{1}{2-s^{g}} \text {. }
$$

It is clear from (88) that the equilibrium level of output does not depend on the level of lump-sum tax. It also implies that since the share of government expenditures is 
constant over time, the price at period 0 of one unit of consumption goods at period $t$ is given by

$$
q_{t}=\beta^{t}
$$

Given the special functional forms of the utility function, the sum of real value of nominal assets at the beginning of period 0 and the expected present-value at period 0 of maximum income flows is independent of the level of lump-sum tax. Recall that the first-order condition for consumption at period 0 can be written as

$$
c_{0}=\frac{a_{0}+v_{0}}{e_{0}}
$$

and the expected-present value of expenditures flows evaluated at the consumer's optimum can be written as

$$
e_{0}=\frac{3}{1-\beta} .
$$

Substituting (88) and (91) into (90), we have

$$
a_{0}+v_{0}=\frac{3\left(1-s^{g}\right)}{(1-\beta)\left(2-s^{g}\right)},
$$

making it clear that in equilibrium allocations will be independent of the lump-sum tax, $z$. When lump-sum taxes are constant, the present-value of maximum income flows becomes

$$
v_{0}=\frac{1-z}{1-\beta} .
$$

Subtracting (93) from (92), we can see that the real value of nominal assets at the beginning of period 0 is affected by lump-sum tax:

$$
a_{0}=\frac{1}{1-\beta}\left[\frac{1-2 s^{g}}{2-s^{g}}+z\right] .
$$

The two components of wealth, $v_{0}$ and $a_{0}$, are affected in exactly offsetting ways by lump-sum taxes.

Of course, with lump-sum taxes the (log) substitution effect is zero. To compute the wealth effect in the conventional decomposition and revaluation effect in our approach, suppose that the government permanently changes lump-sum taxes from $z^{*}$ to $z^{\dagger}$ at period 0 . The wealth effect is given by

$$
\frac{a_{0}^{*}+v_{0}^{\dagger}}{a_{0}^{\dagger}+v_{0}^{\dagger}}=1+\frac{\left(2-s^{g}\right)\left(z^{*}-z^{\dagger}\right)}{3\left(1-s^{g}\right)},
$$

while the revaluation effect is

$$
\frac{a_{0}^{\dagger}+v_{0}^{\dagger}}{a_{0}^{*}+v_{0}^{\dagger}}=\left[1+\frac{\left(2-s^{g}\right)\left(z^{*}-z^{\dagger}\right)}{3\left(1-s^{g}\right)}\right]^{-1} .
$$


Although higher taxes have offsetting effects on the two components of wealth, for $z^{\dagger}>z^{*}$, the effect through full income is unambiguously negative, while the effect through revaluation of assets is unambiguously positive.

The price level change from one tax regime to the other can also be written as

$$
\frac{P_{0}^{\dagger}}{P_{0}^{*}}=\frac{1-2 s^{g}+z^{*}\left(2-s^{g}\right)}{1-2 s^{g}+z^{\dagger}\left(2-s^{g}\right)} .
$$

Figure 1 shows the three effects for changes in the level of lump-sum taxes. Permanently higher taxes, $z^{\dagger}>z^{*}$, reduce full income and its present value, $v_{0}$. With consumption and leisure normal goods, this lower wealth reduces planned consumption, as the top left panel of the figure shows. At the same time, higher taxes raise the expected discounted present value of primary surpluses plus seigniorage, driving down the initial price level and generating a positive revaluation effect, as shown in the right panels of the figure. Analysis that overlooks the revaluation effect would mistakenly infer that a tax hike lowers output through the conventional wealth effect. But this result cannot be an equilibrium. Accounting for the revaluation effect shows that, in equilibrium, a change in lump-sum taxes is neutral with respect to output. Higher taxes nonetheless have price level effects that, in an environment with heterogeneous households, would have distributional consequences.

5.4.2. Equilibrium prices and quantities. Returning to the case of income taxes, we now compute equilibrium prices and allocations. Again we assume that perfectly competitive firms produce their products using a linear technology, $y_{t}=h_{t}$. In addition, wages and prices are fully flexible. Given the linear technology, the real wage is $w_{t}=1$ in each period $t \geq 0$. The share of government expenditures in output is constant, $g_{t} / y_{t}=s^{g}$ for $t \geq 0$. The equilibrium level of output is

$$
y_{t}=\frac{1-\tau_{t}}{2-s^{g}-\tau_{t}}
$$

and the real price at period 0 of one unit of consumption goods at period $t$ is

$$
q_{t}=\beta^{t} \frac{\left(1-\tau_{0}\right)\left(2-s^{g}-\tau_{t}\right)}{\left(1-\tau_{t}\right)\left(2-s^{g}-\tau_{0}\right)} .
$$

The expected present-value of full income flows is

$$
v_{0}=E_{0} \sum_{t=0}^{\infty} \beta^{t}\left[\frac{\left(1-\tau_{0}\right)\left(2-s^{g}-\tau_{t}\right)}{2-s^{g}-\tau_{0}}\right],
$$

and the present-value budget constraint can be written as

$$
a_{0}+v_{0}=\frac{3}{1-\beta} \frac{\left(1-\tau_{0}\right)\left(1-s^{g}\right)}{2-\tau_{0}-s^{g}} .
$$


From (98) it is apparent that direct tax revenues, $\tau_{t} y_{t}$, are quadratic in $\tau$, implying the existence of a Laffer curve. Revenues reach a maximum at $\bar{\tau}=2-s^{g}-$ $\sqrt{\left(2-s^{g}\right)\left(1-s^{g}\right)}$.

5.4.3. Revaluation effect of permanent tax changes. The fiscal authority maintains a constant income tax rate. It follows from (98) that the equilibrium level of consumption, $c_{t}=\left(1-s^{g}\right) y_{t}$, is constant. Now we show that with monetary policy pegging the nominal interest rate according to (83), tax policy can determine a unique equilibrium price level given an initial level of nominal assets. The real price at period 0 of one unit of consumption goods at period $t$ turns out to be $q_{t}=\beta^{t}$. Substituting this into the expected present value of full income flows, we have

$$
v_{0}=\frac{1-\tau}{1-\beta} .
$$

Substituting this into the present-value budget constraint leads to

$$
a_{0}=\frac{1-\tau}{1-\beta} \frac{1-2 s^{g}+\tau}{2-s^{g}-\tau} .
$$

The equilibrium price level at period 0 is now given by

$$
P_{0}=\frac{1-\beta}{1-\tau} \frac{2-s^{g}-\tau}{1-2 s^{g}+\tau}\left(B_{-1}+M_{-1}\right) .
$$

Sufficient conditions for a positive price-level are

$$
0<\beta<1,0 \leq \tau<1,0 \leq s^{g}<\frac{1+\tau}{2}, B_{-1}+M_{-1}>0 .
$$

The quadratic expression in $\tau$ in (103) makes it clear that there will also be a type of Laffer curve in the sum of the expected present values of primary surpluses and seigniorage. The presence of two distinct Laffer curves is critical to understanding how tax rate changes affect this economy.

We turn now to an extended Slutsky-Hicks decomposition for this example economy. Equation (75) implies that the lump-sum transfer required for the computation of the substitution effect is

$$
T_{0}^{s}=\left(a_{0}^{*}+v_{0}^{*}\right)\left[\exp \left(\frac{1}{3} \log \frac{1-\tau^{\dagger}}{1-\tau^{*}}\right)-\frac{a_{0}^{\dagger}+v_{0}^{\dagger}}{a_{0}^{*}+v_{0}^{*}}\right],
$$

where

$$
\frac{a_{0}^{\dagger}+v_{0}^{\dagger}}{a_{0}^{*}+v_{0}^{*}}=\frac{\left(1-\tau^{\dagger}\right)\left(2-\tau^{*}-s^{g}\right)}{\left(1-\tau^{*}\right)\left(2-\tau^{\dagger}-s^{g}\right)}
$$

Recall that equations (77), (81), and (82) show how to compute substitution, wealth, and revaluation effects under logarithmic utility. Equation (77) implies that the 
substitution effect of permanent tax policy under nominal interest rate targeting is

$$
\frac{\left.y^{\dagger}\right|_{u_{0}=u_{0}^{*}}}{y^{*}}=\exp \left(\frac{1}{3} \log \frac{1-\tau^{\dagger}}{1-\tau^{*}}\right) .
$$

As expected, the substitution effect of moving to a permanently higher tax rate, $\tau^{\dagger}>\tau^{*}$, is unambiguously negative: planned hours worked, output, and consumption all fall.

The wealth effect is

$$
\frac{\left.y^{\dagger}\right|_{u_{0}=u_{0}^{\dagger}, a_{0}=a_{0}^{*}}}{\left.y^{\dagger}\right|_{u_{0}=u_{0}^{*}}}=\frac{a_{0}^{*}+v_{0}^{\dagger}}{a_{0}^{*}+v_{0}^{*}}\left[\exp \left(-\frac{1}{3} \log \frac{1-\tau^{\dagger}}{1-\tau^{*}}\right)\right],
$$

where

$$
\frac{a_{0}^{*}+v_{0}^{\dagger}}{a_{0}^{*}+v_{0}^{*}}=\frac{\left(1-\tau^{*}\right)\left(1-2 s^{g}+\tau^{*}\right)+\left(1-\tau^{\dagger}\right)\left(2-\tau^{*}-s^{g}\right)}{3\left(1-\tau^{*}\right)\left(1-s^{g}\right)} .
$$

The revaluation effect is

$$
\frac{y^{\dagger}}{\left.y^{\dagger}\right|_{u_{0}=u_{0}^{\dagger}, a_{0}=a_{0}^{*}}}=\frac{a_{0}^{\dagger}+v_{0}^{\dagger}}{a_{0}^{*}+v_{0}^{\dagger}}
$$

where

$$
\frac{a_{0}^{\dagger}+v_{0}^{\dagger}}{a_{0}^{*}+v_{0}^{\dagger}}=\frac{3\left(1-\tau^{\dagger}\right)\left(1-s^{g}\right)\left(2-s^{g}-\tau^{*}\right)}{\left(2-\tau^{\dagger}-s^{g}\right)\left(3\left(1-\tau^{*}\right)\left(1-s^{g}\right)-\left(\tau^{\dagger}-\tau^{*}\right)\left(2-s^{g}-\tau^{*}\right)\right)} .
$$

Evidently, substitution and wealth effects do not generally offset each other, as one finds with additively separable logarithmic preferences in a static setting [Salanie (2003)]. A special case in which the two effects do cancel arises under a balanced budget, where $\tau=s^{g}$. ${ }^{19}$

Figures 2-4 plot the various effects of a permanent change in tax rate over three ranges of rates. At low tax rates it appears that the revaluation effect on the level of output rises monotonically with the tax rate, while the revaluation effect on the initial price level falls monotonically [figure 2]. This result is consistent with the case of lump-sum taxes. Figures 3 and 4, however, undermine this consistency. At medium tax rates the revaluation effect on output and the price level is non-monotonic [figure 3 ], while at high tax rates the monotonicity reappears, but the sign of the effect has changed from the lump-sum tax case [figure 4].

Figure 5 reveals the source of the non-monotonicity. The model generates two distinct Laffer curves. A conventional Laffer curve finds that the direct tax revenue

\footnotetext{
${ }^{19}$ Decision rules for labor differ in the static and dynamic models. Consider the static problem $\max _{(c, h)} \log (c)+\log (1-h)$ subject to $c \leq(1-\tau) w h$, where households take $\tau$ and $w$ as given. The solution is a decision rule that makes labor constant, $h=1 / 2$, and independent of policy. The analogous problem in the dynamic model in the text yields the decision rule $h=\left(1-s^{g}-\tau\right) /\left(1-s^{g}\right)$, which clearly depends on both government spending and the tax rate.
} 
flow $\left(\tau_{t} y_{t}\right)$ is maximized at a relatively high tax rate of 58.6 percent. In contrast, the present value of primary surpluses plus seigniorage - the object that determines the revaluation effect and the price level under the fiscal theory - is maximized at a much lower rate of 26.8 percent. At tax rates below 26.8 percent, higher rates raise this present value. This lowers the price level, raises the value of initial nominal assets, and induces a positive revaluation effect on output. At rates above 26.8 percent, higher rates reduce the present value of surpluses plus seigniorage and the process is reversed. The reversal arises from the disincentive effects created by higher rates of labor income taxation, which reduce output, equilibrium real balances - the seigniorage tax baseand, when monetary policy pegs the nominal interest rate, seigniorage revenues. This phenomenon underscores the importance of modeling tax distortions, even when the primary interest is the fiscal theory of the price level.

Although the details appearing in figure 5 are specific to the example economy, the principle that when the fiscal theory is operative the economy exhibits two distinct Laffer curves is general. Precisely what the two curves look like depends on model specification and parameter assumptions.

5.5. Contrasting Active and Passive Monetary and Fiscal Policies. A more complete understanding of how monetary and fiscal policies interact to determine the equilibrium can be achieved by contrasting active and passive policy behavior. To illustrate the revaluation effect produced by the fiscal theory, section 5.4 assumes active fiscal policy in the form of an exogenous sequence of tax rates, $\left\{\tau_{t}\right\}_{t=0}^{\infty}$, and passive monetary policy in the form of a pegged nominal interest rate satisfying $1+i_{t}=1 / \beta$, making money supply endogenous. We now consider an alternative policy assumption that monetary policy is active, setting an exogenous sequence of money stocks, $\left\{M_{t}\right\}_{t=0}^{\infty}$, while fiscal policy passively adjusts tax rates endogenously to be consistent with equilibrium.

For simplicity, assume that both the tax rate and the money stock are constants: $\tau_{t}=\tau$ and $M_{t}=M$, all $t \geq 0$. It follows from (98) that consumption and output are constant over time. The constant money supply fixes the price level from period 0 onward. The Euler equation therefore implies that the nominal interest rate is $i_{t}=(1-\beta) / \beta$ in each period $t \geq 0$. Consequently, the demand for real money balances at period 0 can be rewritten as follows:

$$
M_{0}=P_{0} y_{0} \frac{1-s^{g}}{1-\beta} .
$$

Using (98) for $y_{0}$ in the money demand equation (113), we have

$$
P_{0}=\frac{(1-\beta)\left(2-s^{g}-\tau\right)}{\left(1-s^{g}\right)(1-\tau)} M_{0} .
$$


Based on the assumption that the income tax rate is independent of the money supply, one might be tempted to conclude from (114) that, as predicted by simple quantity theories of money, the price level is proportional to the money supply. But it turns out that the equilibrium price level may not be proportional to the money supply, even when the money supply is exogenously specified. Substituting (104) into (114), the relationship between the money stock and income tax rate is:

$$
M_{0}=\frac{1-s^{g}}{1-2 s^{g}+\tau}\left(B_{-1}+M_{-1}\right) .
$$

Equation (115) makes clear that there is one-to-one correspondence between the money stock and income tax rate in equilibrium, given the initial level of nominal assets and the share of government expenditures. Equation (115) can be rewritten as

$$
\tau=\frac{\left(1-s^{g}\right)\left(B_{-1}+M_{-1}\right)}{M_{0}}-\left(1-2 s^{g}\right) .
$$

Substituting (116) into (114), we can see that the relationship between the price level and money supply can be written as

$$
P_{0}=\frac{1-\beta}{1-s^{g}} \frac{3 M_{0}-\left(B_{-1}+M_{-1}\right)}{2 M_{0}-\left(B_{-1}+M_{-1}\right)} M_{0} .
$$

A set of sufficient conditions for a positive price level is

$$
0<\beta<1,0<s^{g}<1,2 M_{0}>B_{-1}+M_{-1} .
$$

The non-linearity of the relationship between the money supply and price level that appears in (117) derives from the presence of a distorting income tax. In contrast, when only lump-sum taxes exist, the price level is proportional to the money supply. To see this, recall that with lump-sum taxes, equilibrium output is:

$$
y_{0}=\frac{1}{1-2 s^{g}} \text {. }
$$

Substituting (119) into the money demand equation, (113), the relationship between the price level and money supply is given by

$$
P_{0}=\frac{(1-\beta)\left(1-2 s^{g}\right)}{1-s^{g}} M_{0}
$$

indicating that with lump-sum taxes, the equilibrium price level is proportional to the money supply. This holds true even though there is one-to-one correspondence between the money supply and the lump-sum tax.

We now turn to the discussion of active and passive monetary policies based on the relationship between the income tax and money stock described above. An example of active monetary policy regime is the case where the central bank chooses a level of the money stock at period 0 and maintains it from period 0 onward, regardless of 
the income tax rate and the share of government expenditures. Specifically, a regime of active monetary and passive fiscal policies is that the income tax rate, denoted by $\tau$, is endogenously chosen to satisfy equation (115), once a level of $M_{0}$ is exogenously set by the central bank. An example of passive monetary and active fiscal policies, in contrast, is the case where the money stock $M_{0}$ is endogenously determined to satisfy equation (115), given that the fiscal authority chooses an income tax rate exogenously.

An immediate consequence of the distinction between active and passive monetary policy regimes is that revaluation of nominal assets can take place even when monetary policy is active. ${ }^{20}$ Under the regime of active monetary and passive fiscal policies, with constant tax rates revaluation effects can arise from changes in the price level induced by exogenous changes in money supply.

\section{Concluding Remarks}

This paper has emphasized that changes in tax policies can have effects on the macro economy by changing the equilibrium price level and, therefore, the value of nominal government assets held by private agents. This mechanism, which we dubbed "the revaluation effect," is always present, whether the price level is determined by the fiscal theory or by some other, more conventional route. The paper derived the revaluation effect as a natural extension of the standard Slutsky-Hicks decomposition, grounding the idea in conventional price theory. When the fiscal theory of the price level is operative, the revaluation effect is the first step in the transmission mechanism for fiscal policy.

To date, virtually all expositions of the fiscal theory have employed the convenient artifice of lump-sum taxes. Assuming that taxes do not distort leads to an unambiguous prediction of the fiscal theory: higher taxes increase the value of nominal government liabilities and lower the price level. This result is appealing because it accords with traditional Keynesian notions that tax hikes reduce aggregate demand. This paper has shown, by way of example, that the Keynesian result is not general, as it relies on there being little or no supply-side effect from tax changes. In the presence of distorting taxes, when the fiscal theory is operative there are two distinct Laffer curves associated with labor income tax rates. The first is the usual one arising from the disincentive effects of high tax rates; this is the effect that Laffer (1979) himself emphasized. The second, which is unique to the fiscal theory, involves the expected discounted present value of primary surpluses plus seigniorage. When tax hikes always raise this present value - as they always do when taxes do not distort - the usual

\footnotetext{
${ }^{20}$ Note that the revaluation effect does not arise under a certain set of active monetary policies. For example, the revaluation effect does not take place when the central bank successfully targets a zero inflation rate from period 0 onward.
} 
fiscal theory result obtains and the price level falls. But if tax rates are high enough to be on the "wrong" side of this second Laffer curve, higher taxes might reduce the present value and raise the price level. Importantly, there is no tight connection between the positions of the two Laffer curves.

Relating the theoretical insights of this paper to actual data remains an open area of research. 


\section{Appendix A. More General Preferences}

In this appendix, we analyze the case where the elasticity of intertemporal substitution is constant but not equal to 1 . We maintain additive separability between consumption and leisure. Specifically, we assume that the utility function is given by

$$
u\left(c_{t}, m_{t}\right)+v\left(1-h_{t}\right)=\kappa_{1} \frac{c_{t}^{1-\sigma}-1}{1-\sigma}+\kappa_{2} \frac{m_{t}^{1-\sigma}-1}{1-\sigma}+\kappa_{3} \frac{\left(1-h_{t}\right)^{1-\sigma}-1}{1-\sigma},
$$

where $\kappa_{1}, \kappa_{2}$, and $\kappa_{3}$ are positive. It then follows from (46) that the expected presentvalue of expenditures turns out to be

$$
e_{0}^{1+\theta}=\frac{1}{1-\sigma}\left\{\left(a_{0}+v_{0}\right)^{\theta} \sum_{t=0}^{\infty}\left(\beta^{\frac{1}{\sigma}}\right)^{t} E_{0}\left[\eta_{t}\right]-\frac{\kappa_{1}+\kappa_{2}+\kappa_{3}}{1-\beta}\right\},
$$

where $\theta=-\frac{1-\sigma}{\sigma}$ and $\eta_{t}$ is defined as

$$
\eta_{t}=q_{t}^{\theta}\left\{k_{1}^{\frac{1}{\sigma}}+\kappa_{2}^{\frac{1}{\sigma}}\left(\frac{R_{t}-1}{R_{t}}\right)^{\theta}+\kappa_{3}^{\frac{1}{\sigma}}\left(\left(1-\tau_{t}\right) w_{t}\right)^{\theta}\right\} .
$$

Hence, we can use this equation to show that the relationship between the expected present-values of expenditures under the two tax regimes can be written as

$$
\left(\left.e_{0}^{\dagger}\right|_{u_{0}=u_{0}^{\dagger}}\right)^{1+\theta}-\left(e_{0}^{*}\right)^{1+\theta}=\frac{1}{1-\sigma}\left\{\left(a_{0}^{\dagger}+v_{0}^{\dagger}+T_{0}^{s}\right)^{\theta}-\left(a_{0}^{*}+v_{0}^{*}\right)^{\theta}\right\} \bar{\eta}_{0}^{*},
$$

where $\theta=-\frac{1-\sigma}{\sigma}$ and $\bar{\eta}_{0}^{o}$ is defined as

$$
\bar{\eta}_{0}^{*}=\sum_{t=0}^{\infty}\left(\beta^{\frac{1}{\sigma}}\right)^{t} E_{0}\left[\left(q_{t}^{*}\right)^{\theta}\left\{k_{1}^{\frac{1}{\sigma}}+\kappa_{2}^{\frac{1}{\sigma}}\left(\frac{R_{t}^{*}-1}{R_{t}^{*}}\right)^{\theta}+\kappa_{3}^{\frac{1}{\sigma}}\left(\left(1-\tau_{t}^{*}\right) w_{t}^{*}\right)^{\theta}\right\}\right] .
$$

On the other hand, recall that the lump-sum transfer $T_{0}^{s}$ is a device to guarantee the same value to value functions that are derived from optimization problems under two different tax regimes. This conditions leads to the following equation:

$$
\left(\frac{\left.e_{0}^{\dagger}\right|_{u_{0}=u_{0}^{\dagger}}}{e_{0}^{*}}\right)^{\theta}=\left(\frac{a_{0}^{\dagger}+v_{0}^{\dagger}+T_{0}^{s}}{a_{0}^{*}+v_{0}^{*}}\right)^{\theta}\left(\frac{\bar{\eta}_{0}^{\dagger}}{\bar{\eta}_{0}^{*}}\right) .
$$

Then, combining (4) and (6), we have a non-linear equation of the form:

$$
\left(e_{0}^{*}\right)^{1+\theta}\left(\left(\frac{\bar{\eta}_{0}^{\dagger}}{\overline{\bar{\eta}}_{0}^{o}}\right)^{\frac{1+\theta}{\theta}} z^{1+\theta}-1\right)=\frac{\bar{\eta}_{0}^{o}}{1-\sigma}\left(a_{0}^{*}+v_{0}^{*}\right)^{\theta}\left(z^{\theta}-1\right),
$$

where $z$ is defined to be

$$
z=\frac{a_{0}^{\dagger}+v_{0}^{\dagger}+T_{0}^{s}}{a_{0}^{*}+v_{0}^{*}}
$$

Solving this equation for $z$ then yields a value of $T_{0}^{s}$, given $a_{0}^{\dagger}, a_{0}^{*}, \bar{\eta}_{0}^{\dagger}, \bar{\eta}_{0}^{*}, v_{0}^{\dagger}$, and $v_{0}^{*}$. 


\section{REFERENCES}

Aiyagari, S. R., And M. Gertler (1985): "The Backing of Government Debt and Monetarism," Journal of Monetary Economics, 16(1), 19-44.

Becker, G. S. (1965): "A Theory of the Allocation of Time," Economic Journal, 75(September), 493-517.

Benigno, P., And M. Woodford (2003): "Optimal Monetary and Fiscal Policy: A Linear-Quadratic Approach," in NBER Macroeconomics Annual 2003. MIT Press, Cambridge, MA.

Blanchard, O. J., and C. M. Kahn (1980): "The Solution of Linear Difference Models Under Rational Expectations," Econometrica, 48(July), 1305-1311.

Brunner, K., And A. H. Meltzer (1972): "Money, Debt, and Economic Activity," Journal of Political Economy, 80(5), 951-977.

- (1993): Money and the Economy: Issues in Monetary Analysis. Cambridge University Press, Cambridge, England.

Buiter, W. H. (2002): "The Fiscal Theory of the Price Level: A Critique," Economic Journal, 112(481), 459-480.

Cochrane, J. H. (2001): "Long Term Debt and Optimal Policy in the Fiscal Theory of the Price Level," Econometrica, 69(1), 69-116.

Eggertsson, G., and M. Woodford (2004): "Optimal Monetary and Fiscal Policy in a Liquidity Trap," Manuscript, Princeton University.

Elmendorf, D. W., and N. G. Mankiw (1999): "Government Debt," in Handbook of Macroeconomics, ed. by J. B. Taylor, and M. Woodford, vol. 1C, pp. 1615-1669. Elsevier Science, Amsterdam.

Friedman, M. (1948): "A Monetary and Fiscal Framework for Economic Stability," American Economic Review, 38(2), 245-264.

York.

Gordon, D. B., and E. M. Leeper (forthcoming): "The Price Level, The Quantity Theory of Money, and the Fiscal Theory of the Price Level," Scottish Journal of Political Economy.

Hall, R. E. (1978): "Stochastic Implications of the Life Cycle-Permanent Income Hypothesis: Theory and Evidence," Journal of Political Economy, 86(6), 971-988. Hicks, J. R. (1939): Value and Capital. The Clarendon Press, Oxford, 2nd edn, 1946 edn.

Jones, L. E., R. E. Manuelli, and P. E. Rossi (1993): "Optimal Taxation in Models of Endogenous Growth," Journal of Political Economy, 101(3), 485-517.

KInG, M. (1995): "Commentary: Monetary Policy Implications of Greater Fiscal Discipline," in Budget Deficits and Debt: Issues and Options, pp. 171-183. Federal 
Reserve Bank of Kansas City, Jackson Hole Symposium.

King, R. G. (1991): "Value and Capital in the Equilibrium Business Cycle Program," in Value and Capital: Fifty Years Later, ed. by L. W. McKenzie, and S. Zamagni. New York University, New York.

King, R. G., And C. I. Plosser (1985): "Money, Deficits, and Inflation," vol. 22 of Carnegie-Rochester Conference Series on Public Policy, pp. 147-196. NorthHolland.

LAffer, A. B. (1979): "Statement Prepared for the Joint Economic Committee, May 20," in The Economics of the Tax Revolt: A Reader, ed. by A. B. Laffer, and J. P. Seymour, pp. 55-59. Harcourt Brace Jovanovich, New York.

Leeper, E. M. (1991): "Equilibria Under 'Active' and 'Passive' Monetary and Fiscal Policies," Journal of Monetary Economics, 27(1), 129-147.

- (1993): "The Policy Tango: Toward a Holistic View of Monetary and Fiscal Effects," Federal Reserve Bank of Atlanta Economic Review, 78(4), 1-27.

- (2003): "Fiscal Policy and Inflation: Pondering the Imponderables," Journal of Investment Management, 1(Second Quarter), 44-59.

Linnemann, L. (2005): "Interest Rate Policy, Debt, and Indeterminacy with Distortionary Taxation," Journal of Economic Dynamics and Control, in press.

Ljungqvist, L., And T. J. Sargent (2004): Recursive Macroeconomic Theory. MIT Press, Cambridge, MA, 2nd edn.

Salanie, B. (2003): The Economics of Taxation. MIT Press, Cambridge.

Sargent, T. J., And N. Wallace (1981): "Some Unpleasant Monetarist Arithmetic," Federal Reserve Bank of Minneapolis Quarterly Review, 5(Fall), 1-17.

Schmitt-Grohe, S., And M. Uribe (2004a): "Optimal Fiscal and Monetary Policy under Imperfect Competition," Journal of Macroeconomics, 26(2), 183-209.

- (2004b): "Optimal Fiscal and Monetary Policy under Sticky Prices," Journal of Economic Theory, 114(2), 198-230.

Sims, C. A. (1994): "A Simple Model for Study of the Determination of the Price Level and the Interaction of Monetary and Fiscal Policy," Economic Theory, 4(3), 381-399.

Slutsky, E. (1915): "Sulla teoria del bilancio del consumatore," Giornali degli economisti e rivista di statistica, 51(series 3), 1-26.

- (1952): "On the Theory of the Budget of the Consumer," in Readings in Price Theory, ed. by K. E. Boulding, and G. J. Stigler, pp. 27-56. Irwin, Homewood, IL.

TAYlor, J. B. (1993): "Discretion versus Policy Rules in Practice," vol. 39 of Carnegie-Rochester Conference Series on Public Policy, pp. 195-214. North Holland. 
Tobin, J. (1961): "Money, Capital, and Other Stores of Value," American Economic Review (Papers and Proceedings), 51(2), 26-37.

— (1969): "A General Equilibrium Approach to Monetary Theory," Journal of Money, Credit and Banking, 1(1), 15-29.

- (1980): Asset Accumulation and Economic Activity. University of Chicago Press, Chicago.

Walsh, C. (2003): Monetary Theory and Policy. MIT Press, Cambridge, MA, second edn.

Woodford, M. (1994): "Monetary Policy and Price Level Determinacy in a Cashin-Advance Economy," Economic Theory, 4(3), 345-380.

— (1995): "Price-Level Determinacy Without Control of a Monetary Aggregate," vol. 43 of Carnegie-Rochester Conference Series on Public Policy, pp. 1-46. North-Holland.

(2003): Interest and Prices: Foundations of a Theory of Monetary Policy. Princeton University Press, Princeton, N.J. 
Tax from 10\%-50\% of Output
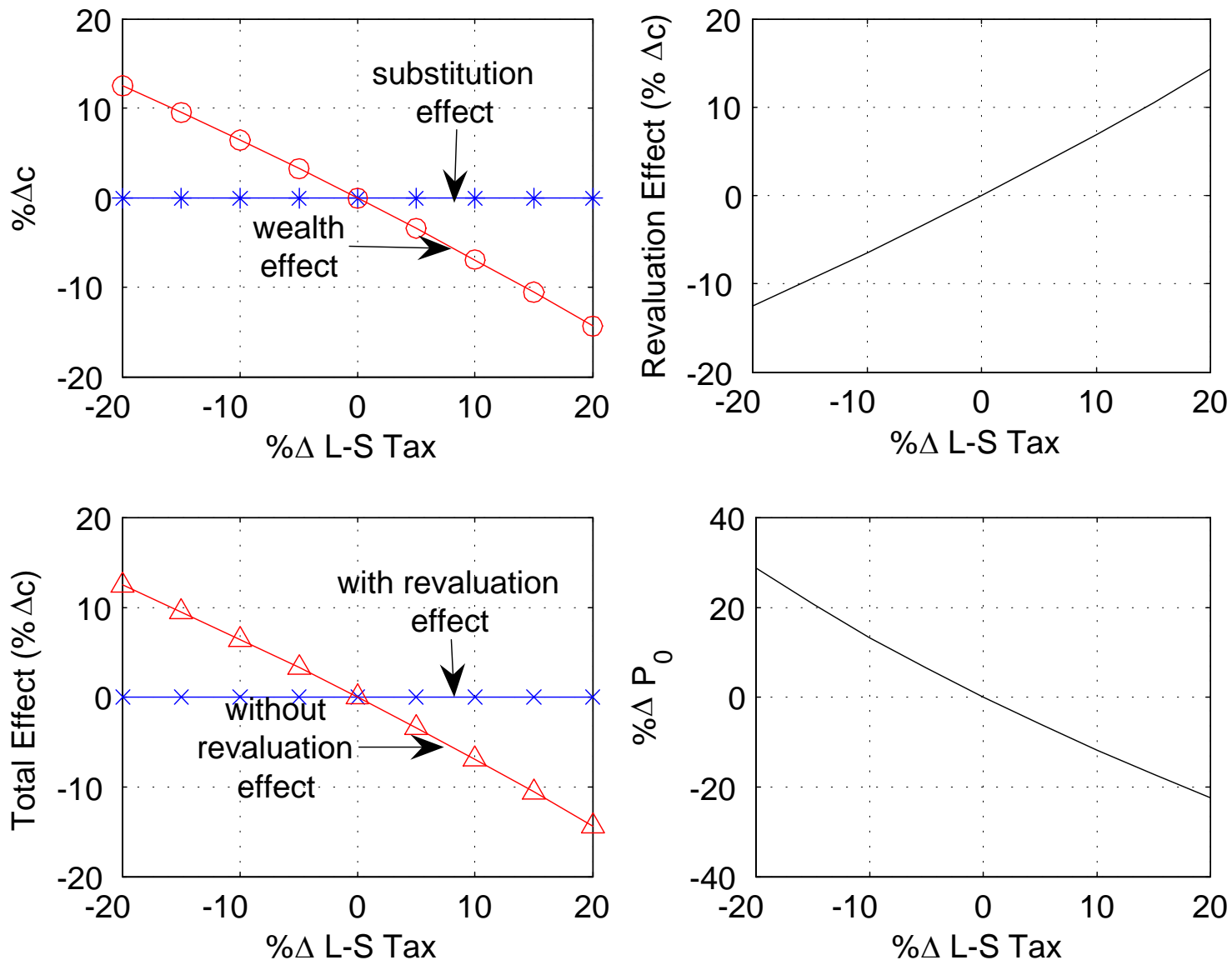

Figure 1. The effects of changes in lump-sum taxes with elastic labor supply and flexible prices. 


\section{$\tau \in[0, .25]$}
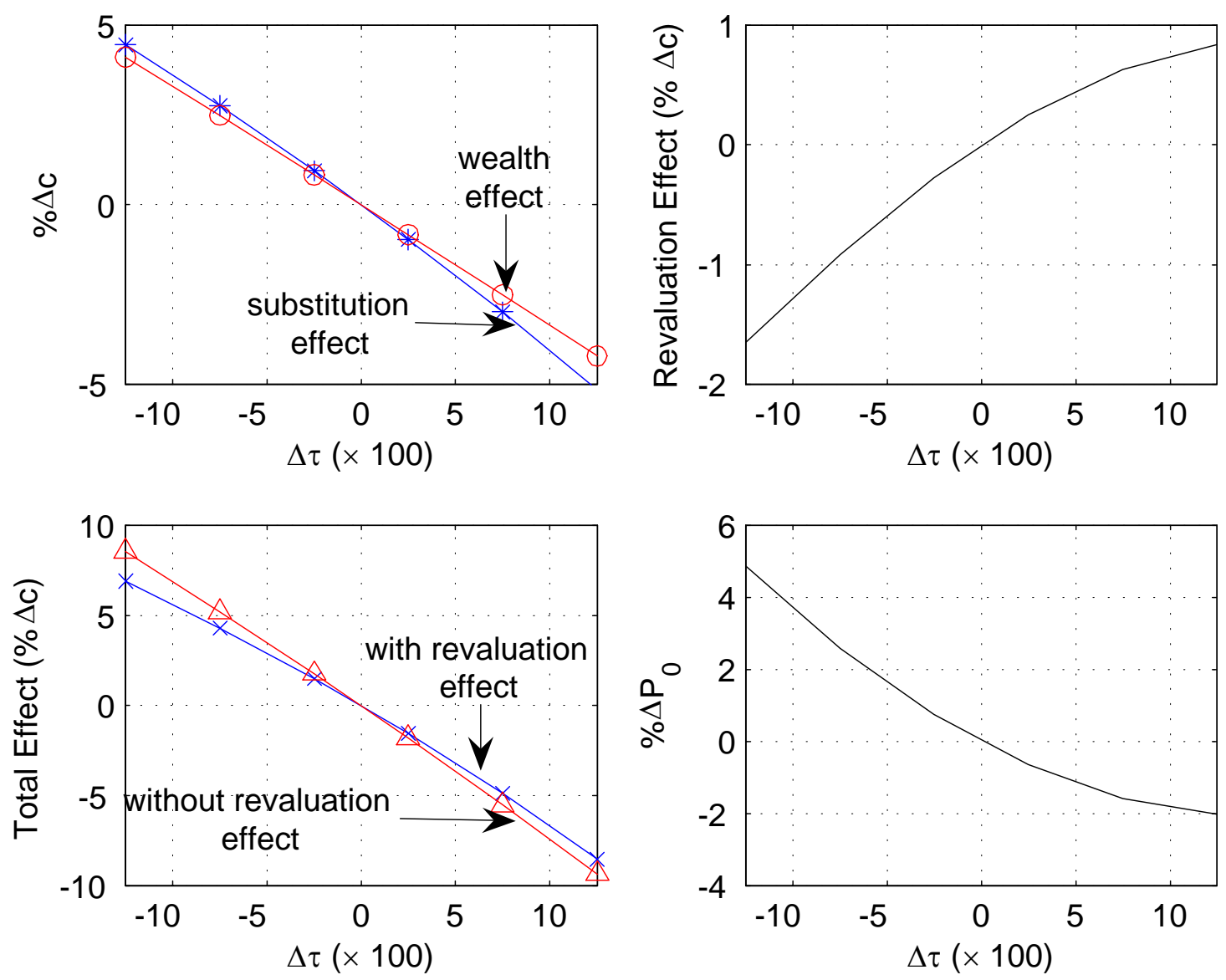

FigurE 2. The effects of permanent changes in income tax rates, $\tau \in[0, .25]$. 


$$
\tau \in[0, .5]
$$
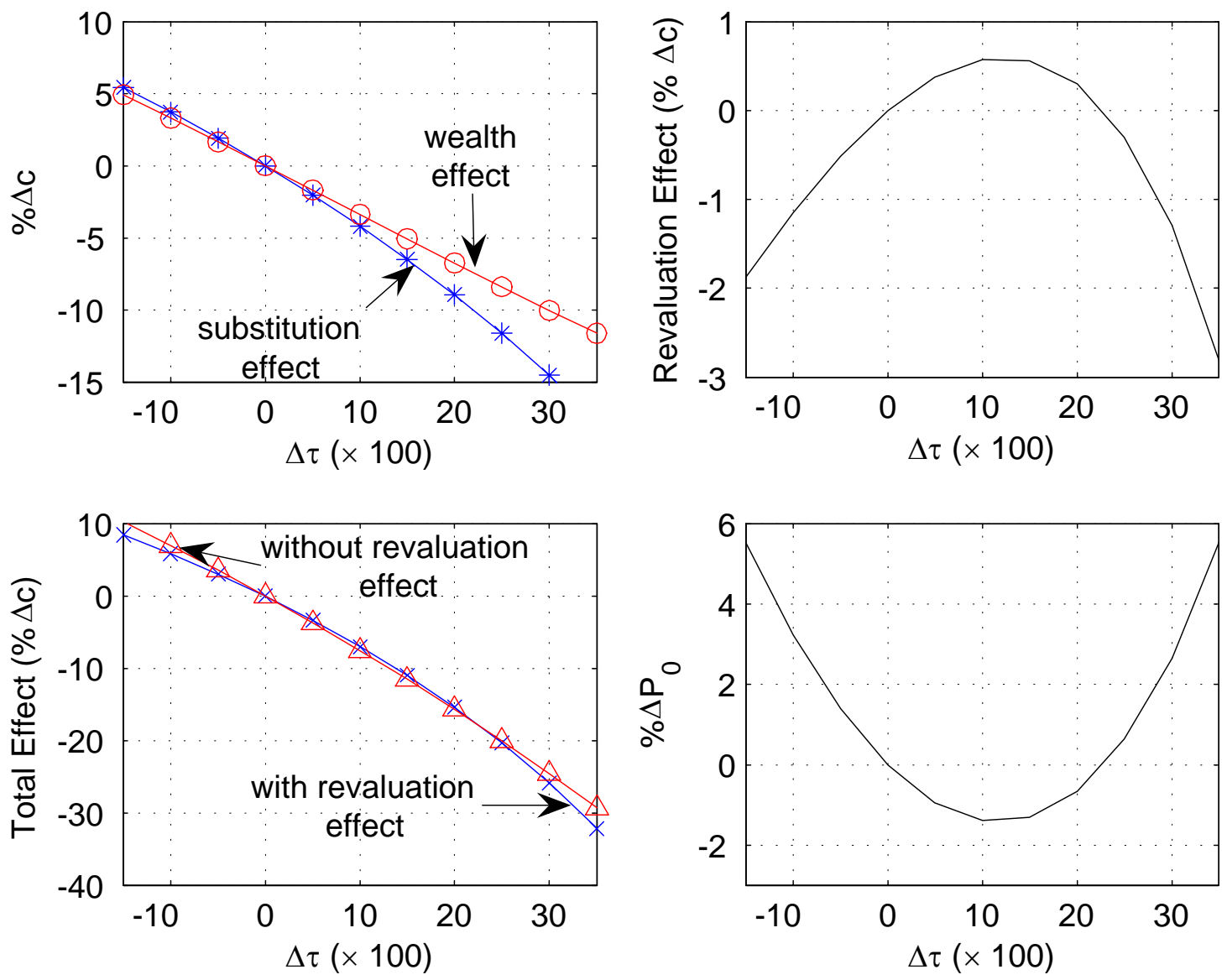

Figure 3. The effects of permanent changes in income tax rates, $\tau \in[0, .5]$. 


$$
\tau \in[.5,9]
$$
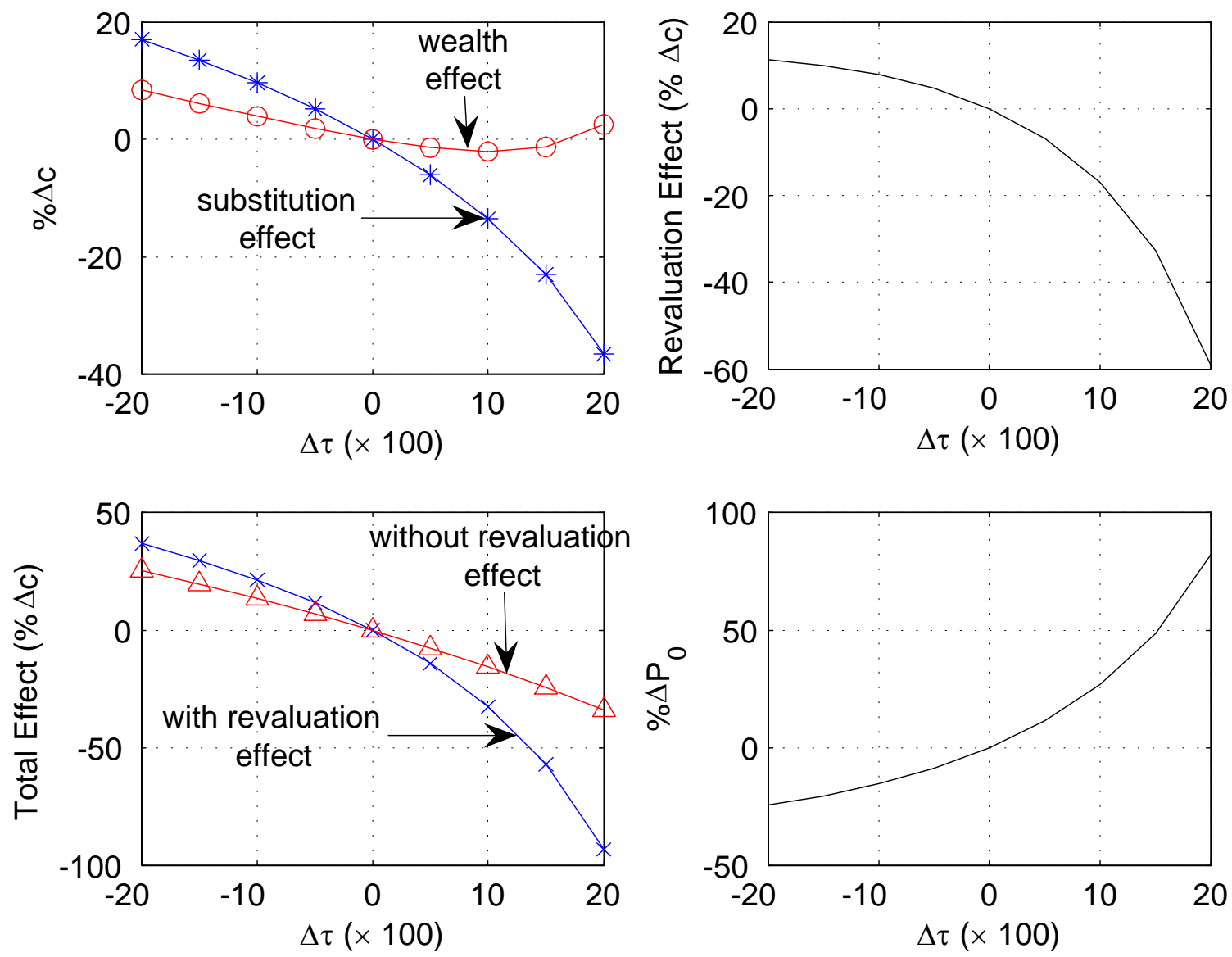

FIGURE 4 . The effects of permanent changes in income tax rates, $\tau \in[.2, .8]$. 


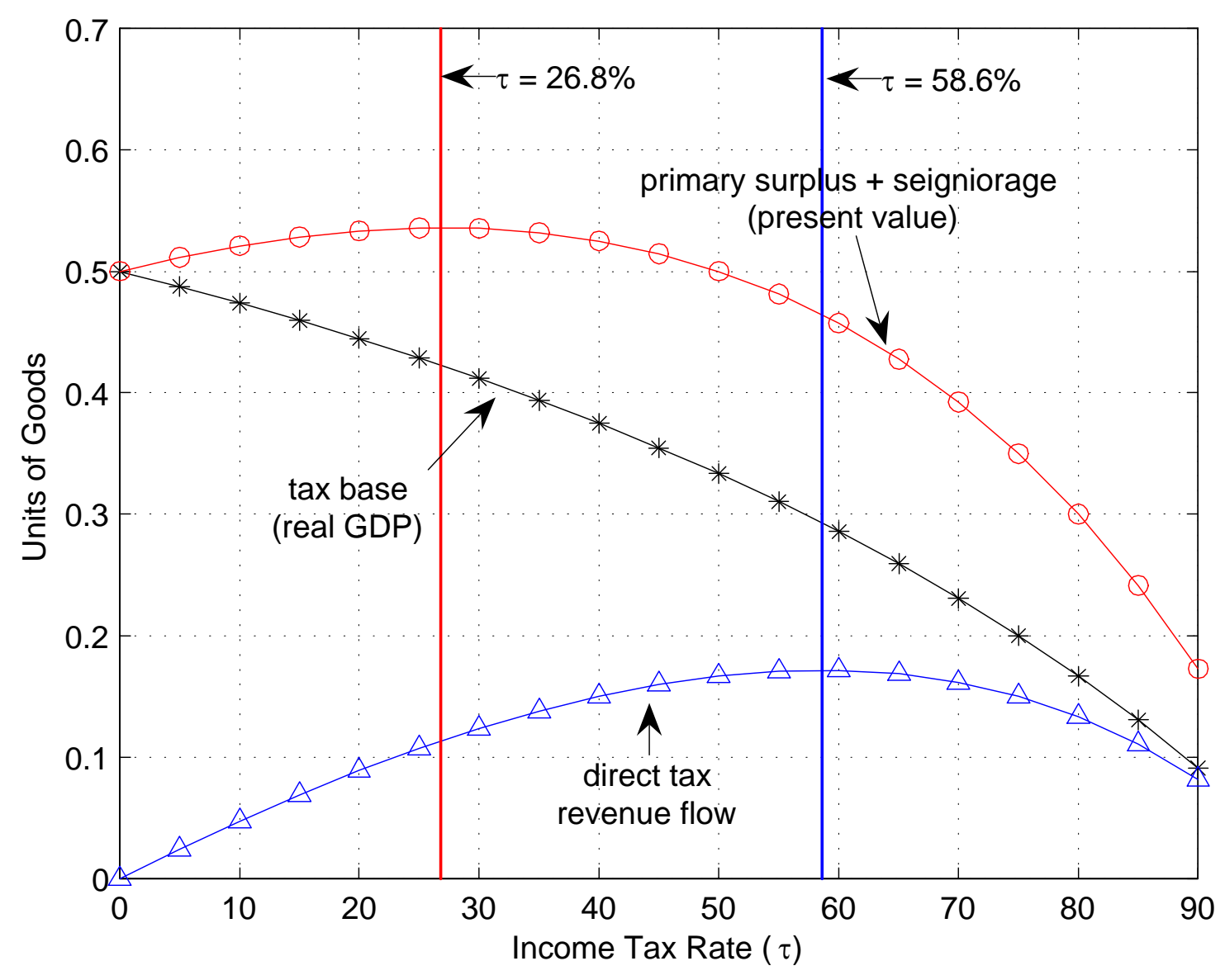

FiguRE 5. Effects of income tax rate on tax base, tax revenue flows, and the present value of primary surpluses plus seigniorage. Vertical lines labeled with tax rates denote maxima. 